\title{
Niewykorzystany kapitał. Pomoc międzynarodowa a początki rehabilitacji zawodowej w Polsce po II wojnie światowej
}

\author{
Unused Assets. International Aid and the Birth \\ of Vocational Rehabilitation in Poland after \\ the Second World War
}

In 1946, at the request of the Polish government, UNRRA sent in two British experts in vocational rehabilitation to help establish the national framework of helping people with disabilities. During numerous meetings with government representatives, medical doctors, and social workers, as well as by trainings, lectures, and screenings of instructional films, they tried to familiarise Poles with the British model of rehabilitation. The model assumed close integration of medical and vocational rehabilitation and aimed at placing the disabled workers in the industry alongside those without disabilities. Initially, officials from the Polish Ministry of Labour and Social Welfare seemed to be keen to adopt such an approach, but in 1949, they turned toward the Soviet solutions. One of the main effects of this shift was moving away from employing the disabled in the industry. They were encouraged to join cooperatives instead, which, in the end, proved to be unfavorable to their social rehabilitation. The article reconstructs the activity of the British experts in Poland and analyses their observations from the encounters. By situating these events in a broader context of political and social conditions, I argue that replacing the progressive British model with Soviet solutions stemmed from the ongoing process of the Sovietization of Poland.

Keywords: disability, cooperatives, physical medicine and rehabilitation, vocational rehabilitation, UNRRA

Słowa kluczowe: niepełnosprawność, spółdzielczość, rehabilitacja zawodowa, rehabilitacja medyczna, UNRRA

\section{Wstęp}

Zgodnie z definicją Światowej Organizacji Zdrowia rehabilitacja to zestaw środków mających na celu pomoc osobom, które doświadczają lub mogą doświadczyć niepełnospraw- 
ności w optymalnym funkcjonowaniu w relacji z otoczeniem ${ }^{1}$. Środki te obejmują działania z zakresu medycyny oraz przysposobienia zawodowego, stąd wyróżnia się dwa typy, a właściwie etapy rehabilitacji - medyczną, czyli leczniczą, oraz zawodową, nazywaną też społeczną ${ }^{2}$. Po II wojnie światowej potrzeba takiego kompleksowego podejścia do dobrostanu osób z niepełnosprawnościami z trudem przebijała się do świadomości Polaków. Aż do początku lat pięćdziesiątych nie udało się zintegrować obu tych sfer. Działo się tak, pomimo że ostatecznym celem rehabilitacji medycznej było przygotowanie osób niepełnosprawnych do rehabilitacji zawodowej, jak zauważał jej pionier Aleksander Hulek, psycholog z wykształcenia ${ }^{3}$. W 1952 r., gdy obejmował stanowisko krajowego konsultanta w tej dziedzinie, rehabilitacja zawodowa „miała już zorganizowane zręby”, medyczna natomiast była dopiero w początkowym stadium rozwoju ${ }^{4}$. Działał tu przede wszystkim Wiktor Dega, który jeszcze przed wojną cieszył się opinią świetnego chirurga ortopedy5. Jemu również powierzono stanowisko konsultanta krajowego, ale do problemu niepełnosprawności, głównie ruchowej, podchodził początkowo od strony czysto medycznej. Z czasem przedstawiciele obu nurtów zaczęli poszerzać zakres swojej działalności, sfery medycyny i przygotowania zawodowego stopniowo przenikały się nadając polskiej praktyce rehabilitacyjnej bardziej kompleksowy charakter.

Dwutorowa geneza polskiej rehabilitacji widoczna jest również w jej historiografii. Rozwój koncepcji rehabilitacji medycznej w ośrodkach ortopedyczno-chirurgicznych omawiają obszernie Mariusz Lubecki ${ }^{6}$, Sławomir Jandziśs i Jerzy Kiwierski ${ }^{8}$. Na temat ewolucji poglądów na metody i cele rehabilitacji zawodowej pisał natomiast Aleksander Hulek ${ }^{9}$, a później także Marianna Marek-Ruka ${ }^{10}$. Z kolei ideowe uwarunkowania rozwoju rehabilitacji zawodowej w pierwszych latach po wojnie opisał Mikołaj Brenk ${ }^{11}$. Cechą wspólną

1 World Health Organization and World Bank, World report on disability 2011, Genewa 2011, s. 308, apps.who. int/iris/handle/10665/44575 [dostęp 20.04.2020].

2 Zwięzły przegląd tych działań oraz podstawowe definicje w zakresie rehabilitacji omawia m.in. M. Marek-Ruka, Rehabilitacja społeczna osób niepełnosprawnych, Warszawa 1999, s. 7-10.

3 W czasie wojny ukończył Studium Pedagogiczne na Uniwersytecie w Edynburgu. Po powrocie do Polski, w lutym 1948 r. znalazł zatrudnienie w Ministerstwie Pracy i Opieki Społecznej. Szybko stał się specjalistą w zakresie czynnościowej analizy pracy osób z niepełnosprawnościami, głównie inwalidów wojennych, co znalazło odbicie w jego pracy naukowej, bowiem już w 1951 r. obronił pracę doktorską na temat doboru pracy dla osób niepełnosprawnych w przemyśle.

4 A. Hulek, Teoria i praktyka rehabilitacji inwalidów: analiza w aspekcie fizycznym, psychologicznym, społecznym i zawodowym, Warszawa 1969, s. 11. Hulek stwierdzał, że zręby te powstały „dzięki inicjatywie jednostek”, nie wyjaśnił jednak jakich.

5 Związany był z Uniwersytetem Poznańskim, gdzie wyspecjalizował się w leczeniu wrodzonych zwichnięć stawu biodrowego. Od 1950 r. przeszedł do Akademii Medycznej i w tamtejszej klinice, którą kierował, wdrażał swoją koncepcję kompleksowego leczenia chorych z upośledzoną czynnością narządu ruchu. Dega uważany jest za pioniera rehabilitacji medycznej, podobnie jak inny chirurg, Marian Weiss ze Szpitala Chirurgii Kostnej w Konstancinie.

6 M. Lubecki, Rola ośrodków rehabilitacyjno-ortopedycznych w polskim modelu rehabilitacji medycznej w drugiej połowie XX wieku, rozprawa doktorska, Uniwersytet Medyczny im. Karola Marcinkowskiego w Poznaniu, Poznań 2010.

7 S. Jandziś, Rehabilitacja lecznicza w okresie Polskiej Rzeczypospolitej Ludowej, „Przegląd Medyczny Uniwersytetu Rzeszowskiego i Narodowego Instytutu Leków w Warszawie" t. 8, 2010, z. 4, s. 505-511.

8 Rehabilitacja polska 1945-2009, red. J.E. Kiwerski, Wrocław 2009.

9 A. Hulek, Z dziejów polskiej rehabilitacji inwalidów i innych osób niepełnosprawnych jako służby społecznej, Warszawa 1998.

10 M. Marek-Ruka, op. cit.

11 M. Brenk, Aktywizacja osób niepełnosprawnych w propagandzie Polski Ludowej lat 1946-1956, [w:] Reintegracja - Edukacja - Adaptacja. Aktywizacja zawodowa i społeczna osób zagrożonych wykluczeniem, red. M. Kowalski, A. Knocińska, P. Frąckowiak, Gniezno 2015, s. 312-323. 
piśmiennictwa obu nurtów jest odwoływanie się do tradycji tzw. polskiego modelu (lub szkoły) rehabilitacji. O ile jednak opracowania zorientowane „medycznie” jego autorstwo przypisują Dedze, to nurt „zawodowy”, dziś związany z dyscypliną pedagogiki specjalnej, tytuł ten oddaje Hulkowi. Dość zgodnie za to za ważny element polskiego modelu rehabilitacji uznaje się spółdzielczość inwalidzką ${ }^{12}$, określaną niekiedy mianem zjawiska unikalnego na skalę światową, o czym pisze m.in. Henryk Waszkowski ${ }^{13}$. Opracowania obu nurtów, koncentrując się na podkreślaniu wyjątkowości i oryginalności polskiego modelu rehabilitacji, równie konsekwentnie pomijają kwestię ewentualnego wpływu, jaki na rozwój polskiej praktyki rehabilitacyjnej mogłyby mieć doświadczenia zagraniczne.

Niniejszy artykuł uzupełnienia tę lukę poprzez omówienie dziejów programu pomocowego UNRRA, w ramach którego w latach 1946-1948 do Polski trafiło kilku brytyjskich specjalistów z zadaniem wsparcia polskich władz w pracach nad stworzeniem nowoczesnego systemu rehabilitacji zawodowej osób z niepełnosprawnościami. Na wykładach i kursach, które prowadzili, a także podczas wielu spotkań z polskimi lekarzami i pracownikami socjalnymi przekazywali doświadczenie rehabilitacji brytyjskiej, uważanej wówczas za wiodącą w Europie ${ }^{14}$. Wpływ tych kontaktów widać wyraźnie w późniejszej działalności naukowej i zawodowej polskich pionierów rehabilitacji ${ }^{15}$. Podczas pobytu w Polsce Brytyjczycy starali się przekonać Polaków, że niepełnosprawni to nie obciążenie, lecz „kapitał pracowniczy", tak bardzo potrzebny w procesie odbudowy kraju. Artykuł stawia tezę, że polskie władze, mimo wyrażanego początkowo entuzjazmu, nie skorzystały z tej rady, przejmując w 1949 r. wzorce radzieckie.

W pracy wykorzystano głównie źródła archiwalne dokumentujące działalność najważniejszych instytucji zaangażowanych w prace nad stworzeniem polskiego programu rehabilitacji zawodowej w pierwszych latach powojennej odbudowy. Przede wszystkim była to Administracja Narodów Zjednoczonych do Spraw Pomocy i Odbudowy (United Nations Relief and Rehabilitation Administration - UNRRA), Ministerstwo Pracy i Opieki Społecznej (MPiOS), a także brytyjskie resorty pracy (Ministry of Labour) oraz rent i emerytur (Ministry of Pensions). Dokumenty pochodzą z archiwów Organizacji Narodów Zjednoczonych w Nowym Jorku, Archiwum Narodowego Wielkiej Brytanii w Londynie, Archiwum Instytutu Polskiego i Muzeum im. gen. Sikorskiego w Londynie oraz Archiwum Akt Nowych w Warszawie. Tak szeroki zestaw źródeł, dotąd w większości niewykorzystywanych w pi-

12 W artykule tym unikam zwrotu określającego osoby z niepełnosprawnościami mianem „inwalidów”. Jednakże słowo to, a także jego pochodne, stosuję w cytatach, nazwach własnych instytucji, tytułach prac drukowanych i aktów prawnych, a w końcu - w tradycyjnie ugruntowanych związkach frazeologicznych typu „inwalida wojenny”, „spółdzielczość inwalidzka”, „spółdzielnia inwalidów” czy „zaopatrzenie inwalidzkie”. Formy te stosuję wyłącznie dla zapewnienia czytelności artykułu w relacji do źródeł historycznych.

13 H. Waszkowski, Ruch spółdzielczości inwalidów i jego znaczenie dla rozwoju rehabilitacji osób niepełnosprawnych w Polsce, "Niepełnosprawność” 2016, nr 4, s. 97-122. Tezę o tej wyjątkowości podważają historycy gospodarczy, którzy zajmują się bardziej ekonomicznym niż rehabilitacyjnym aspektem działalności spółdzielni inwalidów. Zob. P. Grata, Czas przełomu. Polska polityka społeczna w latach 1944-1950, Rzeszów 2018, s. 235-244.

14 Raporty z pobytu brytyjskich ekspertów w Polsce, na ogół bardzo szczegółowe, obejmują dziesiątki nazwisk polskich lekarzy, urzędników oraz przedstawicieli organizacji społecznych, z którymi się spotykali. Pojawiają się tam nazwiska m.in. Hulka i Degi. United Nations Archives [UNA], S-1297-0000-0431, nlb., 7.05.1948 r.

15 Dotyczy to przede wszystkim Hulka, któremu przypisuje zdefiniowanie w 1957 r. rehabilitacji jako przywracania zdolności do samodzielnego życia i pracy „poszkodowanym na zdrowiu inwalidom”. Jest to niemal dosłowne powtórzenie przesłania, które pozostawili brytyjscy specjaliści wyjeżdżając z Polski dziesięć lat wcześniej. M. Marek-Ruka, op. cit., s. 7. 
śmiennictwie, pozwala na wieloaspektowe ujęcie tematu, a odnalezione relacje brytyjskich uczestników opisywanych wydarzeń oferują spojrzenie na początki rehabilitacji w Polsce z zewnętrznej, nieznanej dotąd perspektywy.

\section{Problem do rozwiązania}

Jak we wrześniu 1945 r. informował z Warszawy Ralph Hewins, reporter The Daily Mail, stan zdrowia publicznego w Polsce był wręcz tragiczny ${ }^{16}$. Oprócz danych o liczbie ofiar wojny i chorych oraz doniesień o brakach kadrowych i niedostatku zaopatrzenia medycznego w szpitalach, brytyjski dziennikarz wspomniał o problemie zaopatrzenia protetycznego amputantów. Liczbę osób z amputowanymi kończynami szacowano na 36 tysięcy w skali kraju, a ogólną liczbę niepełnosprawnych na 300 tysięcy ${ }^{17}$. Potrzeby samej Warszawy Hewins oceniał na przynajmniej 11 tysięcy protez. Przed wojną produkowano je w Warszawie, Poznaniu, Krakowie i we Lwowie. Stołeczna fabryka została niemal zrównana z ziemią podczas powstania warszawskiego ${ }^{18}$. Wytwórnia w Poznaniu nie działała z powodu braku surowców, toteż jedynym dostawcą sztucznych rąk i nóg zaraz po wyzwoleniu był Kraków. Zakłady te upaństwowiono i oddano pod zarząd Zakładu Ubezpieczeń Społecznych (ZUS). Działała również bliżej nieokreślona liczba protezowni prywatnych, ale te niewielkie na ogół warsztaty, pracujące w systemie rzemieślniczym, nie były w stanie sprostać zapotrzebowaniu. Nic dziwnego, że - jak pisał Hewins - „jeśli już okaleczona osoba jakimś cudem wyżebrała w Warszawie sztuczną nogę, to kosztowała ona 25 do 30 tysięcy złotych, czyli około 600 dolarów"19. Polacy radzili sobie więc, jak mogli, i na ulicach zniszczonej Warszawy „często można było spotkać mężczyzn, a nawet dzieci bez nóg, wspierających swe ciało na kawałkach drewna, do którego przymocowane były kółka od wrotek"20.

Komentując raport Hewinsa, ambasador Wielkiej Brytanii, Victor Cavendish-Bentinck, nie przeczył, że sytuacja zdrowotna Polaków była „żałosna”, ale uważał, że reporter nieco przesadzał. Hewins opierał się na oficjalnych informacjach, które - zdaniem ambasadora - były zawyżone, ponieważ polskim władzom zależało na utrzymaniu jak najbardziej dramatycznego obrazu sytuacji „w nadziei, że w ten sposób otrzymają więcej wsparcia zza granicy"21. Pomoc taką Polska rzeczywiście otrzymywała, głównie od UNRRA, której sposób działania zakładał ścisłą współpracę z lokalnymi władzami. W efekcie oferowane przez nią programy pomocowe były formułowane w odpowiedzi na zapotrzebowanie zgłaszane przez rządy wspieranych państw22.

Kwestia pomocy niepełnosprawnym Polakom była dyskutowana w sierpniu 1945 r. podczas sesji Rady UNRRA w Londynie. Po tym, jak miesiąc wcześniej Wielka Brytania

16 The National Archives [TNA], FO 688/32/11, nlb, 25.09.1945 r.

17 UNA, S-1393-0000-0033, nlb., 26.08.1946 r.

18 Uruchamiano ją stopniowo, zaczynając od wyrobu butów ortopedycznych na początku grudnia 1945 r. „Głos Narodu" t. 1, 1945, nr 248.

19 TNA, FO 688/32/11, nlb, 25.09.1945.

20 Archiwum Akt Nowych [AAN], MPiOS, sygn. 405, k. 59.

21 TNA, FO 688/32/11, nlb., 28.09.1945 r.

22 Wyczerpującej analizy aktywności UNRRA w Polsce dokonali ostatnio Józef Łaptoś w książce Humanitaryzm i polityka. Pomoc UNRRA dla Polski i polskich uchodźców w latach 1944-1947, Kraków 2018, oraz Jacek Zygmunt Sawicki w książce Misja UNRRA w Polsce: raport zamknięcia (1945-1949), Lublin 2017. 
i Stany Zjednoczone oficjalnie uznały komunistyczny rząd Edwarda Osóbki-Morawskiego w Warszawie, to właśnie jego delegaci zostali zaproszeni na sesję zamiast, jak dotychczas, przedstawicieli rządu na uchodźstwie. Delegaci z Warszawy, którym przewodniczył minister żeglugi i handlu zagranicznego, Stefan Jędrychowski, przekazali kierownictwu UNRRA listę najpotrzebniejszych dostaw medycznych ${ }^{23}$. Oprócz 43 tysięcy łóżek szpitalnych, 100 ton DDT (niezbędnego w walce z epidemią tyfusu) i fabryki penicyliny znalazło się na niej wyposażenie do produkcji protez ${ }^{24}$. Do prośby tej Polacy załączyli szczegółowy spis maszyn i urządzeń określający takie detale, jak parametry tokarek, ciężar kowadła czy średnice wierteł.

\section{Protezy to za mało}

W MPiOS zdawano sobie sprawę, że protezy, a nawet cała ich fabryka, to nie wszystko, aby trwale pomóc wielu tysiącom niepełnosprawnych Polaków, a zwłaszcza inwalidom wojennym. Trzeba było zaplanować kompleksowy program wspierania ich w dążeniu do samodzielności ekonomicznej i społecznej. Ważną rolę w tych planach odgrywały placówki rehabilitacyjne i szkoleniowe, których zadaniem było nie tylko przywracanie niepełnosprawnym sprawności fizycznej, lecz też przygotowywanie ich do podjęcia na nowo pracy zawodowej. Przed wojną ośrodki takie działały w Poznaniu, Krakowie, Warszawie i Niepołomicach ${ }^{25}$. Po wyzwoleniu sieć tych instytucji odbudowywano dość mozolnie. W 1946 r. otwarto ośrodek w Michałowicach na Dolnym Śląsku oraz dom opieki połączony z placówką szkoleniową dla niewidomych weteranów wojennych w Jarogniewicach koło Poznania. To wciąż było jednak za mało w stosunku do potrzeb.

Organizacji efektywnej pomocy osobom niepełnosprawnym na pewno nie sprzyjała mnogość zaangażowanych $w$ to instytucji. Opiekę medyczną nad inwalidami wojennymi finansował ZUS, a przygotowaniem zawodowym zajmował się Wydział Spraw Inwalidzkich (WSI) w MPiOS. Z kolei tworzenie miejsc pracy dla osób z niepełnosprawnościami było zadaniem państwowych urzędów pracy. Z myślą o lepszej koordynacji działań wiosną 1946 r. zaczęto przygotowania do utworzenia na bazie WSI Głównego Urzędu Inwalidzkiego (GUI), który od razu podjął działalność pod tym szyldem, mimo że do formalnego powołania urzędu doszło niemal rok późnieje ${ }^{26}$. Prezesem GUI został Tadeusz Ćwik, były referent do spraw inwalidzkich w resorcie pracy i opieki społecznej rządu RP na uchodźstwie. Po tym, jak jego przełożony, minister Jan Stańczyk, wpływowy polityk Polskiej Partii Socjalistycznej (PPS) opowiedział się po stronie komunistycznego Tymczasowego Rządu

Dieje realizacji programu budowy fabryki penicyliny oraz dzieje pomocy UNRRA w odbudowie polskiego przemysłu protez omawia m.in. Sławomir Łotysz, Penicylina i protezy. Pomoc UNRRA w odbudowie polskiego przemysłu medycznego po I/ wojnie światowej, „Kultura Współczesna: teoria, interpretacje, krytyka” 2018 nr 3, s. 118-130.

25 „Życie Warszawy” t. 2, 1945, nr 223.

26 UNA, S-1393-0000-0033, nlb., 15.04.1946 r. Urząd został powołany na mocy dekretu z 23.01.1947 r. (zob. Dz.U. 1947 nr 21 poz. 83, Dekret z dnia 23 stycznia 1947 r. o organach administracji zaopatrzenia inwalidzkiego). Dekret powoływał również Państwową Radę Inwalidzką jako najważniejszy organ doradczy i opiniodawczy. W skład Rady, oprócz przedstawicieli instytucji państwowych, weszli również reprezentanci organizacji zrzeszających osoby z różnymi niepełnosprawnościami i stowarzyszeń, m.in. Związku Inwalidów Wojennych $\mathrm{RP}(\mathrm{ZIW})$ 
Jedności Narodowej i w 1945 r. wrócił do Polski, by objąć tekę ministra w rządzie OsóbkiMorawskiego, do kraju wrócił również Ćwik, komunista o przedwojennym rodowodzie ${ }^{27}$.

Pomysł, aby tworząc krajowy system rehabilitacji skorzystać z doświadczenia zagranicznego, zrodził się w MPiOS. W kwietniu 1946 r. Ćwik, wówczas jeszcze dyrektor WSI, podczas spotkania z Rolandem Bergerem, szefem Wydziału Opieki Społecznej i Repatriacji w Misji UNRRA w Warszawie, poprosił go o przysłanie do Polski zespołu trzech specjalistów. Pierwszy miał pomóc w odbudowie struktur polskiego szkolnictwa zawodowego osób z niepełnosprawnościami i przygotować program ich przekwalifikowywania, a drugi - doradzać w kwestii ich zatrudniania w przemyśle. Zadaniem trzeciego była pomoc w uruchomieniu produkcji protez ${ }^{28}$. Stronie polskiej zależało na dłuższym, 3-4 miesięcznym pobycie tych specjalistów, najlepiej w tym samym czasie.

Do zadania odbudowy struktur szkolnictwa zawodowego osób z niepełnosprawnościami początkowo zamierzano zaangażować Eliego D. Antoniu z Kalifornii. Rekomendował go Douglas Brown, pełniący obowiązki szefa warszawskiej Misji UNRRA. Znał go z udziału w akcji pomocy dipisom, jak potocznie nazywano osoby w obozach przejściowych (ang. Displaced Persons - DPs) w okupowanych Niemczech, gdzie Antoniu dał się poznać jako świetny fachowiec ${ }^{29}$. Zdaniem Browna cała trójka ekspertów powinna przyjechać do Polski w jednym czasie i pracować jako jeden zespół. Co do dalszych propozycji personalnych, sugerował zwrócić się o pomoc do Brytyjczyków, do ich ministerstwa pracy oraz do Brytyjskiej Rady Rehabilitacji (British Council for Rehabilitation - BCR) ${ }^{30}$.

Sprawa udziału ekspertów zagranicznych w zorganizowaniu „racjonalnej pomocy inwalidom wojennym" w Polsce była tematem narady, jaką zwołano w MPiOS w połowie maja 1946 r. Uczestniczył w niej Stańczyk, który po powrocie z emigracji ponownie objął tekę ministra, a ze strony UNRRA - Berger. Byli też przedstawiciele Polskiego Czerwonego Krzyża, Związku Inwalidów Wojennych RP oraz innych organizacji społecznych ${ }^{31}$. Poszukiwania odpowiednich kandydatów trwały przez dłuższy czas. Ich nazwiska ogłoszono dopiero podczas kolejnego, sierpniowego spotkania w ministerstwie. Byli to: Frederick Oliver Pickersgill, inspektor okręgowy ministerstwa pracy w Cambridge, oraz Hugh Ernest Griffiths, chirurg z Albert Dock Hospital w Londynie, a zarazem prezes zarządu $B C R^{32}$. Mieli przyjechać w ciągu najbliższych dwóch tygodni, pierwszy na trzy miesiące, drugi - na od dwóch do trzech tygodni.

27 T. Marczak, Granica zachodnia w polskiej polityce zagranicznej w latach 1944-1950, Wrocław 1995, s. 244246. Z zawodu był kelnerem, aktywnym działaczem nielegalnej przed wojną Komunistycznej Partii Polski (KPP). Zorganizował wówczas kilka akcji strajkowych, za co trafił do więzienia. W 1936 r. został oddelegowany przez nią jako sekretarz polityczny XIII Brygady Międzynarodowej im. Jarosława Dąbrowskiego walczącej w wojnie domowej w Hiszpanii.

28 UNA, S-1393-0000-0033, nlb., 13.04.1946 r.

29 W czasie wojny Antoniu był członkiem stanowej Komisji Siły Roboczej (ang. War Manpower Commission) w Kalifornii i prowadził wykłady na Uniwersytecie Stanforda z zakresu zatrudnienia osób niepełnosprawnych. Zob. E.D. Antoniu, Employment of the Physically Handicapped; Outline of a Series of Lectures by Eli D. Antoniu [...] for a Course Sponsored by Stanford University and under the Engineering, Science and Management War Training Program, [b.m.] 1943.

30 W skład powołanej wiosną $1945 \mathrm{r}$. Rady weszli przedstawiciele towarzystw medycznych i rehabilitacyjnych, instytutów badawczych, uczelni medycznych, stowarzyszeń osób z niepełnosprawnościami oraz instytucji związanych z medycyną pracy. Zob. British Council for Rehabilitation, „British Medical Journal” 21.04.1945 r., s. 564.

31 „Gazeta Ludowa" t. 2, 1946, nr 136.

32 UNA, S-1393-0000-0033, nlb. 26.08.1946 r. W naradzie uczestniczyli Ćwik i Szankowski z MPiOS, Berger, Franciszek Bazydło ze Związku Inwalidów Wojennych RP, J. Kamiński z Polskiego Związku Głuchych, mjr S. Krasnodębski z PCK i płk Józef Sęk-Małecki, reprezentujący środowiska kombatanckie. 
Griffiths miał dokonać ogólnego przeglądu sytuacji niepełnosprawnych w Polsce i przygotować na tej podstawie rekomendacje, co do dalszego kierunku działań. Z kolei Pickersgill miał doradzać w przygotowaniu systemu rejestracji osób z niepełnosprawnościami oraz ich zatrudniania. Pobyt obu Brytyjczyków w Polsce został szczegółowo zaplanowany. Ministerstwo zorganizowało serię spotkań z ich udziałem dla przedstawicieli środowisk lekarskich, pracowników pomocy społecznej oraz ośrodków przygotowania zawodowego niepełnosprawnych. Miały one na ogół formę wykładów połączonych z pokazami filmów instruktażowych i zakończonych dyskusją z uczestnikami.

Równolegle rozważano pomysł wysłania polskich lekarzy na szkolenie na Zachodzie. Pomysł taki podsunęło Europejskie Biuro Regionalne UNRRA (ERO) w Londynie wiosną 1946 r. Polacy mogli skorzystać z istniejącej formuły programów stypendialnych, jakie UNRRA oferowała wspieranym krajom. W maju 1946 r. specjalnie w tym celu przyznano Polsce dwa dodatkowe miejsca ${ }^{33}$. Listę kandydatów miał przygotować Ćwik, ale jeszcze w końcu sierpnia nie wiadomo było, kto pojedzie ${ }^{34}$. Z kolei we wrześniu 1946 r. powstał pomysł wysłania na przeszkolenie do Ameryki osoby, która w MPiOS odpowiadała za uruchomienie warszawskiej wytwórni protez; nie wiadomo jednak, czy do tego wyjazdu doszło ${ }^{35}$.

\section{Brytyjski przykład}

Nie wiadomo, czy decydując się na wysłanie do Polski Pickersgilla i Griffithsa, UNRRA kierowała się jedynie ich dyspozycyjnością, czy decyzja ta wynikała z przekonania, że brytyjski model aktywizacji zawodowej osób z niepełnosprawnościami najlepiej nadawał się do zaadoptowania w polskich warunkach. Zarówno w Wielkiej Brytanii, jak i w Polsce istotnym problemem był niedostatek rąk do pracy. Uaktywnienie zawodowe tysięcy osób, które z powodu różnych kondycji fizycznych i psychicznych nie były w stanie podjąć samodzielnej pracy, stwarzało możliwość szybszej odbudowy kraju ze zniszczeń wojennych. Znacząco większe doświadczenie brytyjskie w tym zakresie nie wynikało jednak z działań podjętych po wojnie, ale w jej trakcie, kiedy próbowano zwiększyć nie tyle potencjał przemysłowy, co raczej militarny - niepełnosprawni zastępowali przy produkcji w pełni sprawnych mężczyzn, którzy trafiali do czynnej służby wojskowej.

W 1941 r. w Wielkiej Brytanii wszedł w życie Tymczasowy Plan Szkolenia Zawodowego Inwalidów, który zakładał pomoc w „umieszczaniu inwalidów obojga płci w życiu cywilnym" bez względu na powód ich niepełnosprawności ${ }^{36}$. Początkowo plan obejmował

34 Ibid., 26.08.1946 r. Do realizacji pomysłu doszło dopiero po roku, w lipcu 1947 r., a więc już po wygaśnięciu mandatu tej organizacji i jej rozwiązaniu. ONZ zaoferowała Polsce pięć stypendiów dla osób zajmujących się rehabilitacją osób z niepełnosprawnościami. Dwie z nich miały odbyć przeszkolenie w zakresie produkcji protez ortopedycznych w Stanach Zjednoczonych, kolejna miała poznawać metodę wytwarzania protez ocznych, a trzy pozostałe miały podjąć w Wielkiej Brytanii kurs prowadzenia terapii zajęciowej oraz przysposabiania zawodowego osób z niepełnosprawnościami. „Życie Warszawy” t. 4, 1947, nr 194.

35 UNA, S-1393-0000-0036, nlb., 10.09.1946 r. Dokument wymienia w tym kontekście nazwisko Żołędzkiego. Założenie było takie, że na miejscu zapozna się z procesem produkcyjnym w firmie, która miała dostarczyć wyposażenie do Polski. Ale i tym razem z powodu opóźnień w wyborze dostawcy wyjazd opóźniał się. Zarezerwowane miejsce czekało na Żołędzkiego jeszcze w drugiej połowie października. 
szkolenie między innymi w zakresie stolarstwa, zegarmistrzostwa i naprawy maszyn do pisania. Ważnym elementem tego programu było szkolenie tzw. pracowników amunicyjnych, których kierowano do zakładów zbrojeniowych. Kursy odbywały się w specjalnych ośrodkach szkoleniowych w ścisłej współpracy z zakładami pracy, szpitalami i protezowniami oraz urzędami zatrudnienia. Rok później rozszerzono dostępną liczbę zawodów oraz wprowadzono system zasiłków, które umożliwiały niepełnosprawnym w założeniu własnego warsztatu pracy w tych przypadkach, gdy stopnień i charakter niepełnosprawności nie pozwalał danej osobie na podjęcie pracy w przemyśle. Darmową opieką protetyczną objęto wszystkie osoby, którym posiadanie protez umożliwiało podjęcie pracy zawodowej (dotąd mogli na to liczyć jedynie ci, który utracili kończyny w czasie służby wojskowej).

Jak zauważali brytyjscy lekarze, możliwość podjęcia pracy była główną troską samych niepełnosprawnych. Zwykle była to pierwsza rzecz, o jaką pytali pacjenci wybudzani z narkozy po zabiegu amputacji. Brytyjskie ministerstwo pracy, najwyraźniej świadome wagi tego problemu, przysyłało swoich urzędników już do szpitala, aby tam, na miejscu, oceniali możliwości zatrudnienia pacjenta i wstępnie klasyfikowali jego przydatność do określonych zawodów. W przypadku, gdy mógł pracować w dotychczas wykonywanym zawodzie, biuro pośrednictwa pracy kierowało go bezpośrednio do firmy poszukującej pracowników o konkretnych kwalifikacjach.

Mając na uwadze tych, których stan po opuszczeniu szpitala nie pozwalał na podjęcie szkolenia w ośrodku, od grudnia 1943 r. zaczęto tworzyć specjalne centra rehabilitacji. Trafiały tam osoby, które po zakończonym leczeniu nadal były w niezadowalającym stanie fizycznym lub psychicznym, albo te, które nie mogły się zdecydować, jaką podjąć pracę. Poddawano je dalszemu leczeniu i rehabilitacji leczniczej, a w dobrze wyposażonych warsztatach pozwalano próbować sił w różnych specjalnościach, by mogły wybrać najbardziej odpowiednią dla siebie. Naczelną zasadą było przekonanie pensjonariuszy takiego ośrodka, że nie przebywają w domu dla rekonwalescentów, tylko w zakładzie, którego "głównym hasłem jest szybkie przejście do zdrowia"37. Po pobycie w centrum rehabilitacji większość osób wracała do swojej poprzedniej profesji. Tych, którzy z uwagi na charakter niepełnosprawności nie mogli wykonywać poprzedniego fachu, kierowano do ośrodka szkoleniowego, gdzie przechodzili sześciomiesięczny kurs nowego zawodu w normalnych warunkach pracy. Po rozwiązanie to sięgano stosunkowo rzadko - na 250 tysięcy weteranów II wojny światowej, skorzystało z niego jedynie 16 tysięcy osób38.

Jak wspomniano, gdy na frontach wciąż trwały walki, wielu niepełnosprawnych Brytyjczyków kierowano do pracy w przemyśle zbrojeniowym. Gdy pod koniec wojny zapotrzebowanie na pracowników amunicyjnych zmalało, główny ciężar szkolenia przesunął się na zawody cywilne. Zasadą było przygotowywanie do specjalności najbardziej przydatnych z punktu widzenia odbudowy kraju, czyli tych związanych z branżą budowlaną, mechaniczną i elektrotechniczną. Przy wyborze właściwego fachu zaangażowani byli eksperci ministerstwa, których zadaniem był odwodzenie weteranów od podejmowania zawodów zbyt trudnych i wymagających ${ }^{39}$. Była to duża zmiana w stosunku do praktyki stosowanej 
po I wojnie światowej. Wtedy niepełnosprawny mógł szkolić się w zawodzie, który mu się „najbardziej podobał”, co nie zawsze przynosiło pozytywne skutki ${ }^{40}$.

Terapia zajęciowa w centrach rehabilitacji była ukierunkowana na odbudowę poczucia własnej wartości u inwalidów. Podkreślano to, do czego byli zdolni, a nie to, czego nie byli w stanie wykonać. Brytyjscy specjaliści w zakresie rehabilitacji zaobserwowali, że osobę niepełnosprawną cechuje zwykle "determinacja do opanowania sytuacji” oraz że wykazuje ona „zdumiewającą energię do przezwyciężenia swojej niezdolności do pracy". Może dlatego, jak Griffiths starał się przekonać Polaków, osoba niepełnosprawna na ogół „dostosowuje się bez trudu" do reżymu ośrodka szkoleniowego, a jej przygotowanie zawodowe zajmuje "tyle samo lub niewiele więcej czasu”, co osoby w pełni sprawnej ruchowo ${ }^{41}$.

W końcowym okresie wojny w Wielkiej Brytanii podjęto szeroką akcję propagandową, której celem było przekonanie przemysłu, że zatrudnianie niepełnosprawnych może stanowić rozwiązanie problemu braku rąk do pracy. Od strony prawnej regulowała to ustawa z 1944 r. zobowiązująca pracodawców do zatrudniania procentowo określonej liczby osób zarejestrowanych jako niepełnosprawne. Nie brakowało przypadków, że i samego zainteresowanego trzeba było przekonywać, że nadaje się do pracy ${ }^{42}$.

\section{Jak inspektor pracy z chirurgiem}

Pierwszy do Warszawy dotarł Pickersgill. Już nazajutrz po przyjeździe, 12 września 1946 r., podczas pierwszego spotkania w MPiOS omówił w skrócie brytyjskie doświadczenia w zakresie aktywizacji zawodowej osób z niepełnosprawnościami. Pickersgill zapewniał, że w Wielkiej Brytanii praca osób niepełnosprawnych była uważana przez pracodawców za bardzo produktywną i przywołał przykład warsztatów, gdzie mężczyźni po amputacji rąk heblowali, piłowali i wbijali gwoździe, a po kilkumiesięcznym przeszkoleniu mogli samodzielnie „zrobić stół z doskonale dopasowanymi szufladami”43.

Już pierwsze spotkania uświadomiły mu, że wśród Polaków dominowało przekonanie, iż niepełnosprawni nie nadają się do pracy, a jeśli już, to powinni wykonywać jedynie proste czynności. Brytyjski specjalista uważał, że punktem wyjścia na drodze do aktywizacji zawodowej inwalidów wojennych i cywilnych było przekonanie opinii publicznej, że dzięki protezom i odpowiedniemu przeszkoleniu osoba bez kończyn może wykonywać wszystkie prace, nawet te wymagające precyzji. By tego dowieść, pokazywał brytyjskie filmy szkoleniowe ukazujące osoby pozbawione rąk lub nóg wykonujące różne codzienne czynności: mężczyzna z protezami obu rąk pisał na maszynie, a inny dzięki protezom palców rysował. Jeden z bohaterów filmy, pozbawiony ręki, powiedział: „Zapomnijcie, do czego nie nadaję się z powodu kalectwa, i pozwólcie mnie to zapomnieć, a powiedźcie, co mogę robić i dajcie mi taką pracę"44.

42 UNA, S-1450-0000-0336, nlb., H. Griffiths, Rehabilitation of the Disabled in Poland, 12.11.1946 r., s. 6.

43 AAN, MPiOS, sygn. 404, k. 40.

44 „Gazeta Ludowa” t. 2, 1946, nr 330. 
Pickersgill utrzymywał, że dzięki protezie niepełnosprawny mógł podjąć „współzawodnictwo na równych warunkach z osobami niedotkniętymi inwalidztwem"45, a po odpowiednim przeszkoleniu mógłby podjąć każdą pracę, a „handel uliczny nie jest jedyną możliwością jego zarobkowania"46. Brytyjczyk starał się uczulić Polaków, aby na niepełnosprawnych „nie patrzeć oczyma pełnymi litości - czego oni nie znoszą, uważając się za równowartościowych obywateli kraju"47. Przekonywał, że na niepełnosprawność nie powinno się w ogóle zwracać uwagi, „uznając nowoczesną protezę za dostateczny instrument, który przywróci inwalidę do życia normalnie rozwiniętych ludzi"48. $\mathrm{Na}$ uwagę zwraca pojawienie się w tej narracji wątku techniki jako czynnika re-humanizacji człowieka, który w wyniku chorób, wad wrodzonych czy ran znalazł się poza sferą „normalności" postrzeganej przez pryzmat kompletności jego ciała bądź jego przydatności społecznej.

Griffiths wylądował w Warszawie 8 października 1946 r. Podczas trzytygodniowego pobytu odwiedził wiele fabryk, szpitali, sanatoriów oraz ośrodków rehabilitacyjnych i szkoleniowych. Wszędzie starał się służyć radą, wskazując proste na ogół sposoby poprawy skuteczności procesu przywracania pełnej sprawności zawodowej i społecznej osobom, które ją utraciły w wyniku wojny, choroby lub wypadku. Nie zawsze jednak spotykał się ze zrozumieniem. W jednej z łódzkich tkalni na 6 tysięcy zatrudnionych spotkał jedynie dwóch mężczyzn z niepełnosprawnościami - jeden nie miał nogi poniżej kolana, a drugi dwóch palców u lewej ręki. Zdaniem Brytyjczyka żadne ze stanowisk pracy, które widział, nie wykluczało, by mogła objąć je osoba o znacznie większym stopniu niepełnosprawności, ale dyrektor fabryki był innego zdania ${ }^{49}$. Podczas tego samego pobytu w Łodzi Griffiths spotkał się z Henrykiem Dinterem, dyrektorem Centrum Szkolenia Pracowników Opieki Społecznej, w którym regularnie wykładał Pickersgill. Griffiths odniósł wrażenie, że choć był to świetny i zaangażowany fachowiec, to był też „owładnięty ideą, powszechną w Polsce, że rehabilitacja polega na przygotowaniu inwalidów do konkretnej, siedzącej pracy jak szewstwo czy krawiectwo" 50 .

Jeszcze trudniej do zmiany podejścia do problemów osób z niepełnosprawnościami szło mu przekonanie polskiego ministra zdrowia, Franciszka Litwina. Zdaniem ministra kwestia rehabilitacji ograniczała się do wyposażenia weteranów w protezy i ich późniejszego przeszkolenia, a obie te sprawy leżały w kompetencjach MPiOS. Litwin stwierdził dosłownie, że „rehabilitacja nie była zmartwieniem ministerstwa zdrowia”51. Griffiths próbował wprawdzie wyjaśnić, na czym polegała rola resortu zdrowia w brytyjskim modelu rehabilitacji osób niepełnosprawnych, ale Litwin stwierdził, że jego ministerstwa na taką działalność nie stać. Pogląd ten podzielał jego wiceminister, Bogusław Kożusznik. Także on nie wiedział wiele na temat rehabilitacji, ale przynajmniej wysłuchał Griffithsa do końca. Brytyjczyk dowodził, że to nie kwestia pieniędzy, lecz właściwej organizacji, i że

51 Ibid., s. 12. 
całkowity koszt terapii medycznej jest na ogół niższy, jeśli odbywa się ona jako element kompleksowej procedury rehabilitacyjnej, jednak Kożusznika - jak konkludował Griffiths w swoim raporcie - „trudno było przekonać"52.

Zdecydowanie lepsze wrażenie na brytyjskim ekspercie wywarł natomiast minister pracy i opieki społecznej Adam Kuryłowicz. Był zdecydowanie bardziej otwarty na argumenty i chciał dokładnie poznać zasady, na jakich opierał się brytyjski model rehabilitacji. Dyskutując z Griffithsem zalety rehabilitacji krótko- i długotrwałej przyznał, że w rządowych planach rozważano dotychczas jedynie ten drugi wariant ${ }^{53}$. Wychodząc ze spotkania, w którym oprócz Kuryłowicza uczestniczył Charles M. Drury, szef Misji UNRRA w Warszawie, oraz Pickersgill, Griffiths miał wrażenie, że minister „pojął fakt, że w interesie Polski leżało przyjęcie znacznie szerszego programu rehabilitacji" osób z niepełnosprawnościami, niż był planowany ${ }^{54}$. Podczas pobytu w Polsce Griffiths kilkakrotnie spotykał się z Kuryłowiczem. Za każdym razem długo rozmawiali, nie tylko podczas roboczych narad, lecz również na przyjęciach, których w programie pobytu obu Brytyjczyków w Polsce nie brakowało. Minister zamierzał przyjechać do Wielkiej Brytanii, by na miejscu zapoznać się z funkcjonowaniem tamtejszego modelu rehabilitacji.

Jeszcze częściej niż Kuryłowiczem Griffiths widywał się z Ćwikiem, o którym miał jak najlepszą opinię jako o ciężko pracującym człowieku, bez reszty angażującym się w zadanie, które przed nim postawiono ${ }^{55}$. Jesienią 1946 r. Ćwik, jako dyrektor WSI i przyszły prezes organizowanego GUI, zajęty był głównie kwestią rejestracji osób niepełnosprawnych oraz sprawą ich przygotowania zawodowego i zatrudnienia, przy czym, jak stwierdzał Griffiths, „oczywiście skłaniał się" ku metodzie szkolenia długotrwałego w zawodach rzemieślniczych jako podejścia dominującego wówczas w Polsce. Griffiths miał jednak nadzieję, że Ćwik, będąc „pod wrażeniem tego, co usłyszał i co widział na filmach" o amerykańskich i brytyjskich metodach rehabilitacji zawodowej inwalidów, zmieni w tej sprawie zdanie" ${ }^{\prime 56}$. Za otwartość i duże zaangażowanie Griffiths chwalił w swoim raporcie również Stanisława Zdanowskiego i Zbigniewa Świerczyńskiego z dolnośląskiego okręgu Związku Inwalidów Wojennych RP. Obydwaj byli zafascynowani brytyjskim modelem rehabilitacji i z całych sił popierali adaptację jego założeń w Polsce. Zapowiadali, że bez zwłoki zaczną wdrażać to wszystko, czego nauczyli się z wykładów Griffithsa we właśnie uruchomionym centrum rehabilitacji w Michałowicach. Zdanowski i Świerczyński współpracowali z niewymienioną z nazwiska psycholożką z Wrocławia, która miała zająć się prowadzeniem testów predyspozycji zawodowych pensjonariuszy ${ }^{57}$.Ich entuzjazm imponował Griffithsowi tym bardziej, że generalnie napotykał duże trudności, starając się przekonać polskich decydentów, jak duże znaczenie w rehabilitacji odgrywa psychologia. Jak wywnioskował z rozmów z Haliną Diamand z Ministerstwa Przemysłu, w resorcie panowało przekonanie o niewielkiej użyteczności psychologów w procesie doskonalenia metod produkcji bądź analizy predyspozycji pracowników do wykonywania określonych czynności ${ }^{58}$.

58 Griffiths nie pamiętał nazwiska swojej rozmówczyni, jednak bezwątpienia była to Halina Diamand, która reprezentowała ministerstwo przemysłu również podczas spotkań z Pickersgillem. 
W Polsce nikt wówczas nie zajmował się badaniami czasu i ruchu, stosowanymi na Zachodzie od początku XX w. w procesie optymalizacji czasu i miejsca pracy ${ }^{59}$. Zapewnienia Griffithsa, że według doświadczeń brytyjskich po właściwej selekcji nawet $90 \%$ osób z niepełnosprawnościami znajdowało pracę w przemyśle i to bez potrzeby dodatkowego przeszkolenia, jego rozmówczyni przyjmowała „ze zdumieniem, a nawet pewnym niedowierzaniem"60. Zarówno ona, jak i obecny przy tej rozmowie przedstawiciel Ministerstwa Oświaty brali później udział w szkoleniach prowadzonych przez brytyjskiego eksperta. Resort oświaty zobowiązał się do bezzwłocznego powołania katedry psychologii inżynieryjnej na jednej z uczelni wyższych.

To, co jeszcze dziwiło polskich rozmówców Griffithsa, to informacja, że w Wielkiej Brytanii wysokość renty, jaką otrzymywał zarejestrowany inwalida wojenny, nie zależała od tego, czy podejmował dodatkową pracę zarobkową czy nie, co zachęcało do poszukiwania zatrudnienia ${ }^{61}$. Zaskoczenie Eugenii Pragier, wiceminister w resorcie pracy, było jeszcze większe, gdy Griffiths wyjaśnił, że władze brytyjskie nie uzależniały możliwości podjęcia szkolenia zawodowego od stopnia niepełnosprawności. Każdy mógł skorzystać z tego dobrodziejstwa, podczas gdy w Polsce, jak Griffiths wywnioskował z rozmowy, kwalifikowani się do tego jedynie niepełnosprawni z utratą zdrowia nie mniejszą niż 50\%.

Po wyjeździe Griffithsa do Anglii Pickersgill kontynuował swoją działalność jako konsultant MPiOS. Wspólnie z Ćwikiem opracował m.in. system ewidencji osób z niepełnosprawnościami. Przygotowany formularz rejestracyjny $w$ dużym stopniu opierał się na podobnych kwestionariuszach szpitalnych stosowanych w Wielkiej Brytanii. Odpowiedzi na pytania zawarte $w$ formularzu miały pomóc w wyborze najwłaściwszego zawodu. Rejestrację miały prowadzić komisje lekarskie, a nadzór nad całością objęła specjalna podkomisja do spraw analizy czynnościowej pracy osób niepełnosprawnych utworzona przy GUI62. Rejestracja miała ruszyć w końcu listopada 1946 r.

Mimo że obaj brytyjscy eksperci tyle mówili o potrzebie zatrudniania niepełnosprawnych w przemyśle, i to niekoniecznie lekkim, zasadność takiego podejścia nadal z trudem przebijała się do ogólnej świadomości Polaków. Pickersgill widział wielką rolę resortu przemysłu w zmianie tego nastawienia, jak bowiem dowodził, po zakończeniu procesu leczenia osoby z niepełnosprawnościami, „prędzej czy później odpowiedzialność za nią przechodzi z lekarzy na przemysł”. Jak przekonywał, „inteligencja, wiek, doświadczenie, przeszkolenie są o wiele ważniejsze, aniżeli inwa-

59 Badania time and motion lub motion studies, analizujące ruchy robotnika na stanowisku pracy, zostały zainicjowane przez Fredericka Taylora jako metoda optymalizacji produkcji. Metodę tę rozwinął później jego współpracownik inżynier Frank Gilbreth, który wraz z żoną Lillian, psycholożką, zastosowali ją m.in. w optymalizacji pracy chirurgów, ale również przy określaniu możliwości wykonywania określonych czynności przez osoby z niepełnosprawnościami. Zob. F. Gilbreth, L. Gilbreth, Motion Study for the Handicapped, Londyn 1920. Pionierem w przenoszeniu tej koncepcji na grunt polski był Aleksander Hulek. Zob. A. Hulek, Analiza pracy metoda i technika, „Praca i Opieka Społeczna” 1948, nr 4, s. 257-262.

60 UNA, S-1450-0000-0336, nlb., H. Griffiths, Rehabilitation of the Disabled in Poland, s. 15.

61 Ibid., s. 14.

62 Najprawdopodobniej zajmował się tym Hulek, który od lutego 1948 r. pracował w MPiOS. Hulek wspominał, że czynnościową analizą pracy w okresie międzywojennym nikt się w Polsce nie zajmował. Sam najprawdopodobniej bazował na wiedzy zdobytej podczas studiów w Wielkiej Brytanii, inaczej trudno wytłumaczyć, że jego pierwszy artykuł na ten temat ukazał się zaledwie kilka miesięcy po powrocie do kraju. Zob. A. Hulek, Czynnościowa analiza pracy (na marginesie zatrudnienia ciężko poszkodowanych inwalidów w przemyśle), „Praca i Opieka Społeczna" 1948, nr 2, s.101-104. 
lidztwo. O inwalidztwie można zapomnieć, a pamiętać tylko, do czego inwalida jest zdolny"63.

Powodzenie programu rehabilitacji zależało w głównej mierze od przygotowania personelu, który miał ten plan wcielać w życie. Oprócz lekarzy i pracowników społecznych, przeszkolonych podczas kursów prowadzonych przez obu ekspertów, orędownikami nowoczesnej metody rehabilitacji mogli być ci Polacy, którzy zetknęli się z nią w Wielkiej Brytanii. Chodziło tu przede wszystkim o personel medyczny II Korpusu Polskiej Armii. Jeszcze przed przyjazdem do Polski Griffiths prosił o odszukanie porucznika lekarza Eugeniusza Olewicza, który pod jego kierunkiem odbył miesięczną praktykę w Albert Dock Hospital wiosną 1944 r. Griffiths wspominał go jako „kompetentnego i zdolnego człowieka, który byłby bardzo przydatny w programie rozwoju rehabilitacji" planowanym w Polsce ${ }^{64}$. Początkowo myślał, że polski lekarz zginął w trakcie wojny ${ }^{65}$. Dopiero później okazało się, że jak wielu innych żołnierzy II Korpusu zdecydował się zostać w Wielkiej Brytanii na stałe.

Podobnie nie udało się nawiązać kontaktu z innym Polakiem, F. Gilewskim, który w czasie wojny miał styczność z brytyjskim programem rehabilitacji inwalidów ${ }^{66}$. Przez dwa lata pracował w Roehampton w zachodnim Londynie. Mieściło się tam znane w całym kraju centrum rehabilitacji przy Queen Mary's Hospital oraz wytwórnia protez J.E. Hangers \& Co. ${ }^{67}$ Większość jej pracowników stanowili inwalidzi wojenni, głównie po amputacjach kończyn ${ }^{68}$. Zdaniem kierownictwa firmy Gilewski świetnie nadawał się, by jako konsultant UNRRA doradzać przy rozbudowie zdolności produkcyjnych polskich wytwórni protez ${ }^{69}$. Wrócił natomiast Kazimierz Opacki, chirurg przez większą część wojny służący w różnych szpitalach Royal Air Force na Wyspach Brytyjskich. Zanim zdecydował się na powrót do Polski, miał również okazję zapoznać się z działalnością ośrodka w Roehampton ${ }^{70}$.

\section{Więcej niż kontrakt}

Po powrocie do Wielkiej Brytanii Griffiths i Pickersgill przez dłuższy czas żyli wrażeniami z pobytu w Polsce. Regularnie wygłaszali odczyty, udzielali wywiadów i publikowali artykuły, opisując swoje doświadczenia, zarówno te zawodowe, jak i prywatne. Ciekawe spostrzeżenie poczynił Griffiths odnośnie do liczby osób z niepełnosprawnościami w Polsce. Z dostarczonych mu statystyk wynikało, że osób niepełnosprawnych w Polsce było proporcjonalnie mniej niż na przykład w Wielkiej Brytanii czy Stanach Zjednoczonych.

63 AAN, MPiOS, sygn. 404, k. 63.

64 UNA, S-1450-0000-0336, nlb., 16.09.1946 r.

65 Okazji po temu nie brakowało. Por. lek. Olewicz dowodził jednym zespołów kompanii sanitarnej wchodzącej w skład 1. Samodzielnej Brygady Spadochronowej, którą we wrześniu 1944 r. zrzucono w okupowanej Holandii. Zob. A. Rutkiewicz, Służba zdrowia 1. Samodzielnej Brygady Spadochronowej-organizacja, wyszkolenie, działania 1941-1947, rozprawa doktorska, Instytut Historii Nauki im. L. i A. Birkenmajerów PAN, Warszawa 2019, s. 141.

66 UNA, S-1450-0000-0335, nlb., 19.08.1946 r. Nie jest znane pełne imię Gilewskiego.

67 Firma była oddziałem amerykańskiego koncernu założonego przez Jamesa E. Hangera, „pierwszego amputanta Wojny Secesyjnej" i wynalazcy protezy nogi nazywanej jego nazwiskiem. Firma działa do dziś i jest liderem nowoczesnej protetyki. Zob. Hanger, Inc. www.hanger.com/ [dostęp 20.04.2020]

68 F. Illingworth, Limbless Ex-servicemen Now Walk and Work, "The War Illustrated” 1946, nr 229, s. 747-749.

69 Na zapytanie ze strony UNRRA we wrześniu 1946 r. firma wyraziła zgodę na przyjęcie kilku kursantów z Polski. UNA, S-1450-0000-0335, nlb., 19.08.1946 r; UNA, S-1450-0000-0336, nlb., 16.09.1946 r.

70 A. Rutkiewicz, op. cit., s. 177. 
Jego konkluzja „była ponura, lecz prosta - niewielu z nich udało się przetrwać” woj$n e^{71}$. W innym odczycie podkreślił wysokie kwalifikacje polskich chirurgów, z którymi miał okazję się spotkać. Jego zdaniem nie potrzebowali dodatkowego szkolenia w zakresie rehabilitacji medycznej, ponieważ informacje o najnowszych metodach leczenia docierały do nich za pośrednictwem zachodnich czasopism specjalistycznych. Uważał jednak, że w Polsce brakowało specjalistów, którzy wiedzieliby, jak prawidłowo badać pracowników pod kątem ich predyspozycji psychotechnicznych ${ }^{72}$.

Zadania rehabilitacji Griffiths postrzegał znacznie szerzej niż tylko w przywróceniu zdolności poruszania się i zarobkowania osobom, które z powodu niepełnosprawności były tego pozbawione. Jego zdaniem proces ten powinien obejmować nie tylko inwalidów wojennych „bez nóg”, jak to w praktyce miało miejsce w Polsce, lecz też wszystkie ofiary wojny, które możliwość zarobkowania utraciły w wyniku wstrząsu psychicznego wywołanego wojną ${ }^{73}$. Uważał, że Polacy potrzebowali nie tylko pomocy materialnej, lecz i duchowej ${ }^{74}$. Według niego, za „inwalidę, a w każdym razie za człowieka o ograniczonych władzach fizycznych i psychicznych" należało w praktyce uznać nie tylko okaleczonych i rannych, lecz wszystkich mieszkańców zrujnowanych terenów. Jak mówił, zniszczenie to „wżarło się tak głęboko w polskie dusze, że «rehabilitacji» poddać należałoby cały naród"75.

Podczas odczytów prowadzonych po powrocie do Wielkiej Brytanii, zarówno Pickersgill i Griffiths wyrażali nadzieję, że przekazane przez nich sugestie zostaną z pożytkiem wykorzystane dla dobra niepełnosprawnych Polaków. Wyjeżdżali z Polski z przekonaniem, że ich wzorowany na brytyjskim system ewidencji był właśnie wdrażany, i wierzyli, że pozostałe elementu planu rehabilitacji wejdą w życiu niedługo później ${ }^{76}$.

Wydaje się, że w dużej mierze był to jednak optymizm podyktowany względami politycznymi. Oficjalne raporty, które obaj złożyli ze swojej działalności jako konsultanci UNRRA, wskazują, że byli w tej sprawie większymi realistami. Więcej nawet, w pierwszej wersji raport Griffithsa był na tyle bezpośredni, że Drury obawiał się, że upowszechnienie jego treści „mogłoby mieć niefortunne konsekwencje dla relacji z polskim rządem”77. Chodziło przede wszystkim o opinie, jakie Griffiths wyrażał o niektórych ministrach, zapewne te o Litwinie, wobec którego był szczególnie krytyczny. Poza tym w Warszawie mogły się nie spodobać jego komentarze na temat relacji w polskim rządzie. Zdaniem brytyjskiego eksperta pomiędzy resortami zdrowia a pracy i opieki społecznej toczyła się rywalizacja. Ministerstwu Zdrowia, które jego zdaniem miało słabszą pozycję w strukturach władzy, zależało na ograniczeniu zadań rehabilitacji zawodowej do szkolenia osób trwale niepełnosprawnych, przy czym kierownictwo resortu z chęcią pozbyłoby się wszelkich związanych z tym obowiązków na rzecz MPiOS ${ }^{78}$.

Taking the Work Further, „New Poland” 1947, nr 2, s. 12.

„Dziennik Polski i Dziennik Żołnierza” t. 8, 1947, nr 12.

„Gazeta Ludowa” t. 3, 1947, nr 169.

UNA, S-1450-0000-0336, nlb., H. Griffiths, Rehabilitation of the Disabled in Poland, s. 69.

Reportaż ukazał się na łamach czasopisma "London Calling” wydawanego przez BBC, co sugeruje, że został również wyemitowany przez brytyjskie radio. „Gazeta Ludowa” t. 3, 1947, nr 169.

Their Mission to Poland's Disabled, "New Poland” 1947, nr 2, s. 12-13

UNA, S-1450-0000-0337, nlb., 9.12.1946 r.

UNA, S-1450-0000-0336, nlb., H. Griffiths, Rehabilitation of the Disabled in Poland, s. 14. 
W raporcie Griffiths zawarł również komentarze na temat sytuacji politycznej w Polsce. Szczególnie na Dolnym Śląsku zaobserwował bardzo dużą niechęć wobec Rosjan, wyrażaną głównie przez zwykłych robotników. Intelektualiści - odwrotnie: w rozmowach z Griffithsem wyrażali podziw dla rosyjskiej kultury i szkolnictwa wyższego. Wszyscy jednak byli przekonani, że system komunistyczny był nieodpowiedni dla Polski ${ }^{79}$. Dominowała niepewność co do skutków ustania zachodniej pomocy. Jak zauważał Griffiths, panowało „uczucie, a często i strach, że znaczyłoby to dla Polski, że po roku narastających trudności i niedostatków, zostałaby wchłonięta przez wschodniego sąsiada"80.

Podczas pobytu w Polsce Brytyjczyk generalnie spotykał się z przejawami sympatii. Nie był pewien, czy wynikało to ze zwykłej uprzejmości wobec gościa, czy może jakichś cieplejszych uczuć, jakie Polacy mogliby żywić wobec Anglii. Jedyny zarzut wobec Wielkiej Brytanii, z jakim się spotkał, najpewniej w rozmowach z przedstawicielami rządu, dotyczył wsparcia udzielanego przez brytyjski rząd armii Andersa, a także rzekomej pomocy finansowej dla podziemia antykomunistycznego w Polsce ${ }^{81}$.

Pickersgill również zaangażował się w polskie sprawy politycznie, choć patrzył na nie z nieco innej perspektywy. Plan pozostawienia w Wielkiej Brytanii przeszło 140 tysięcy polskich żołnierzy uważał za błąd ${ }^{82}$. Jego zdaniem żołnierzy Andersa należało repatriować do Polski tak samo, jak organizowano powroty Polaków z obozów przejściowych w okupowanych Niemczech. Chodziło mu o to, że stanowili oni ogromny zasób siły roboczej, której Polska pilnie potrzebowała w procesie odbudowy. Świadom był obaw o bezpieczeństwo, jakie żywili zdemobilizowani żołnierze, dlatego proponował, aby „pewną liczbę starannie wybranych Polaków sprowadzić do Polski, by zobaczyli, jak bardzo ich praca jest potrzebna”. Po powrocie do Anglii mieliby służyć jako „misjonarze” zachęcając do powrotu innych ${ }^{83}$.

Blisko trzymiesięczny pobyt w Polsce wywarł na Pickersgillu ogromne wrażenie. Zaraz po powrocie do Anglii przeszedł na emeryturę. Jak pisał później do Ćwika, nadmiar wolnego czasu przeznaczył na „usiłowanie nauczenia się języka polskiego pod kierunkiem polskiej niewiasty" oraz prowadzenie odczytów na temat swoich doświadczeń z pobytu w Polsce ${ }^{84}$. Utrzymywał kontakt z osobami, z którymi współpracował w Polsce, szczególnie $z$ ośrodka $w$ Łodzi. Bezinteresownie oferował pomoc we wszelkich działaniach na rzecz osób z niepełnosprawnościami. Konsultował m.in. program utworzenia centrów szkoleniowych i pomógł urządzić pracownię badania predyspozycji zawodowych osób z niepełnosprawnościami w poradni zawodowej w Łodzi ${ }^{85}$.

79 Ibid., s. 68

80 Ibid., s. 69.

81 Ibid. Jak mu mówiono, wspierane przez Brytyjczyków i Amerykanów oddziały „strzelały do komunistów, Żydów i Rosjan w zasięgu wzroku".

82 „The Observer” 1.09.1946 r. Zamierzano powołać Polski Korpus Przysposobienia i Rozmieszczenia, który po dwóch latach miał formalnie stać się jednostką armii brytyjskiej. Władze w Warszawie protestowały przeciwko tym planom, argumentując, że istnienie pod dowództwem Brytyjczyków polskich oddziałów złożonych z żołnierzy nieukrywających niechętnego stosunku do nowego porządku politycznego w Polsce byłoby zagrożeniem dla pokoju w Europie.

83 UNA, S-1450-0000-0336, nlb, 24.09.1946 r. Drury, z którym Pickersgills rozmawiał na ten temat, powiedział, że działania takie już prowadzono, ale najwyraźniej wybrano niewłaściwe osoby do tego zadania.

84 AAN, MPiOS, sygn. 407, k. 7.

85 AAN, MPiOS, sygn. 405, k. 9 i 56. Chodziło o sprowadzenie do Polski niezbędnej literatury, a także testów wykrywających ślepotę barw, zestawów do badania wyobraźni przestrzennej, aparatury do czynnościowej analizy pracy oraz testów na inteligencję. Okazało się jednak, że UNRRA z powodu rychłego zakończenia działalności 
W kwietniu 1947 r. ONZ poprosiła Pickersgilla, by z podobną misją jako doradca udał się do Czechosłowacji. Początkowo wahał się, ale perspektywa połączenia tego wyjazdu z krótkim pobytem w Polsce skłoniła go do przyjęcia propozycji. Skontaktował się z Ćwikiem i zaoferował swoje usługi jako doradca, ale potrzebował formalnego zaproszenie ze strony ministerstwa ${ }^{86}$. Nie chciał wynagrodzenia, a jedynie oczekiwał zwrotu kosztów utrzymania. Ćwik uruchomił wszystkie kontakty, aby dotrzeć do nowego ministra, Kazimierza Rusinka, i wyjaśnić mu, jakie zasługi Pickersgill oddał sprawie rehabilitacji niepełnosprawnych w Polsce ${ }^{87}$. Licząc, że Brytyjczyk będzie mógł zostać w Polsce przez dwa miesiące, Ćwik przygotował dla niego całą listę zadań: organizację wzorcowego ośrodka przysposobienia do pracy i szkolenia niepełnosprawnych, przygotowanie i przeprowadzenie kursu terapii zajęciowej w takim ośrodku, a także opracowanie programu zatrudnienia inwalidów w przemyśle ${ }^{88}$. Wyjazd do Czechosłowacji znacznie się opóźnił i ostatecznie Pickersgill był w stanie zatrzymać się w Polsce tylko na kilka dni ${ }^{89}$.

\section{Rewizyta, czyli co po nich zostało}

Pickersgill wyjeżdżał z nadzieją, że przekonał Polaków do tego, że „mają kapitał pracowniczy w swoich inwalidach"90. Również Griffiths starał się przekonać polskich ministrów, że odpowiednio przeszkoleni niepełnosprawni „to aktywa, a nie finansowe obciążenie w Narodowym Planie Gospodarczym"19. Okazja, aby się przekonać, czy Polacy rzeczywiście zaakceptowali ten punkt widzenia nadarzyła się półtora roku później.

W końcu 1947 r., podczas wizyty w Wielkiej Brytanii, minister Rusinek poprosił swojego odpowiednika o przysłanie eksperta, który mógłby pomóc w kontynuacji przebudowy krajowego programu pomocy osobom niepełnosprawnym ${ }^{92}$. Jako najlepszego fachowca w tej dziedzinie minister pracy George Isaacs bez wahania zaproponował Griffithsa. Ten, również bez wahania, zgodził się na przyjazd, przedtem jednak został wezwany do resortu spraw zewnętrznych.

Patrick Hancock, który go przyjął, dopytywał się o wrażenia z pierwszej wizyty. Czas najwyraźniej wyostrzył u Griffithsa krytyczną ocenę tego, co wówczas widział. Mówił, że przygotowywany przez Polaków program rehabilitacji był „wyjątkowo prosty i nieefektywny", a władze nawet nie znały dokładnej liczby amputantów. Na dowód „bałaganu”, jaki panował w Polskim Ministerstwie Pracy i Opieki Społecznej, podał przykład kursantki, którą właśnie przysłano do Wielkiej Brytanii, by przeszkoliła się w zakresie wyrobu protez

nie mogła zrealizować tego zamówienia, toteż prośbę przekazano Radzie Zagranicznych Instytucji Pomocy Polsce.

86 AAN, MPiOS, sygn. 405, k. 82.

87 AAN, MPiOS, sygn. 407, k. 14.

88 AAN, MPiOS, sygn. 405, k. 86.

89 Ibid., k. 87 i 92. Ćwik szykował dla niego niespodziankę: w sierpniu MPiOS wystąpiło na jego prośbę o przyznanie Anglikowi Orderu Odrodzenia Polski V klasy za zasługi przy organizacji Państwowych Zakładów Szkolnych dla inwalidów wojennych. Możliwe, że asumpt do podjęcia tych starań dała informacja z początku lipca, że Pickersgill został Kawalerem Orderu Imperium Brytyjskiego. Nie udało się potwierdzić, czy rzeczywiście otrzymał polski order, ani tego, czy jesienią1947 r. rzeczywiście zatrzymał się w Polsce.

90 AAN, MPiOS, sygn. 405, k. 59.

91 TNA, FO 371/71536, nlb. H. Griffiths, Rehabilitation of the Disabled. Poland 1948, s. 38

92 Ibid., s. 3. W delegacji liczącej siedem osób wzięli udział m.in. Ćwik i Lancmański 
oka. Jej zamiar przejścia pięcioletniego kursu w pół roku Griffiths uważał za całkowicie bez sensu. Z kolei mężczyzna, który miał zapoznać się z metodami produkcji protez ortopedycznych, okazał się być ekspertem od lokomotyw ${ }^{93}$.

Griffiths przyleciał do Polski 16 marca 1948 r. Podobnie jak poprzednio, podczas trzytygodniowego pobytu wygłosił kilka wykładów oraz odwiedzał fabryki, szpitale i ośrodki rehabilitacji. W szpitalu w Piekarach Śląskich skonstatował, że pacjentów po amputacjach nie poddawano wstępnej rehabilitacji. Co więcej, nie wyposażano ich nawet w protezy, nie informowano, gdzie mają o nie zabiegać ani gdzie szukać dalszej pomocy ${ }^{94}$. Anglik był świadom, że przyczyną takiego stanu rzeczy nie była ignorancja czy niedbałość, lecz ogromne braki kadrowe. Lekarze byli przepracowani i nie byli w stanie zajmować się swoimi pacjentami po zakończeniu leczenia ortopedycznego.

Od czasu jego pierwszej wizyty niewiele zmieniło się w zakresie dostępności protez. Fabryka w Poznaniu, którą odwiedził, produkowała ledwie 100 sztuk miesięcznie, czyli tyle samo, co półtora roku wcześniej ${ }^{95}$. Griffiths zaznaczył jednak, że jak długo w szpitalach nie powstaną oddziały fizjoterapii i terapii zajęciowej i jak długo nie będzie stałej współpracy szpitali z MPiOS w kwestii rejestracji i przygotowania niepełnosprawnych do pracy, tak długo nie będą oni mogli liczyć na prawdziwą rehabilitację. Uważał, że bez tego główny cel, jakim jest przywrócenie pacjentowi pełnej sprawności, był skazany na porażkę ${ }^{96}$.

Griffiths miał mieszane uczucia co do założeń, według których organizowano centrum rehabilitacji dla 1000 inwalidów w Lęborku, największe tego typu w Europie. Ośrodek powstawał na terenie dawnego niemieckiego szpitala psychiatrycznego ${ }^{97}$. Griffiths sugerował zdecydowaną zmianę wystroju budynków, których architektura, z racji oryginalnego przeznaczenia szpitala, „obliczona była na stworzeniu uczucia represji”98. W centrum planowano urządzenie warsztatów krawieckich, szewskich, zabawkarskich, kapeluszniczych, introligatorskich i mechanicznych. Oprócz szkolenia praktycznego mieszkańcy ośrodka mieli również uczestniczyć w zajęciach teoretycznych. Kierownik do spraw edukacji, z którym Griffiths rozmawiał, był zdeterminowany, aby pensjonariuszom pomóc w odbudowie ich pewności siebie. Uważał jednak, że w działalności zawodowej będą mieli większe szanse na sukces, pracując w grupach niż w pojedynkę. Zamierzano ich zachęcać do tego, aby po opuszczeniu ośrodka zakładali spółdzielnie inwalidów.

Chociaż Brytyjczyk zafascynowany był możliwościami, jakie to miejsce oferowało, to uważał jednak, że pensjonariuszom, czy też raczej kursantom należało zapewnić więcej przestrzeni. W jego opinii z punktu widzenia interesu „narodu i planu gospodarczego” daleko bardziej korzystne było utrzymanie w Lęborku modelowego ośrodka szkoleniowego, niż próba pomieszczenia tam tylu niepełnosprawnych, ile to możliwe. W efekcie, jak nie bez nuty rozczarowania zauważał Griffiths, stworzono w ten sposób „miasteczko”

4 TNA, FO 371/71536, nlb. H. Griffiths, Rehabilitation of the Disabled. Poland 1948, s. 22.

95 Ibid., s. 19. Jednym z powodów był brak łożysk kulkowych. W Polsce ich nie produkowano, a przedwojenny zapas importowanych ze Szwecji łożysk właśnie się kończył.

96 Ibid., s. 43.

97 Obecnie jest to siedziba 1. Lęborskiego Batalionu Zmechanizowanego Wojska Polskiego.

98 TNA, FO 371/71536, nlb. H. Griffiths, Rehabilitation of the Disabled. Poland 1948, s. 34. 
z warsztatami pracy chronionej, a nie ośrodek przygotowania zawodowego ${ }^{99}$. Uważał, że skala problemu rehabilitacji niepełnosprawnych w Polsce wskazywałaby raczej na konieczność skoncentrowania się najpierw na przygotowaniu zawodowym jak największej liczby osób, a dopiero później można było myśleć o budowie takich osad. Mimo wszelkich krytycznych uwag, jakie miał wobec tego projektu, wiedział, że jest on „drogi sercu” ministra Rusinka ${ }^{100}$.

Griffiths był krytycznym obserwatorem, ale potrafił też zmienić zdanie, jeśli uznał argumenty rozmówców za zasadne. W 1946 r. krytykował pomysł szkolenia niepełnosprawnych przede wszystkim do pracy w krawiectwie i szewstwie. W raporcie z drugiej wizyty w Polsce przyznawał natomiast, że polityka taka była podyktowana lokalną specyfiką. Przede wszystkim, jak zauważał, Polacy częściej niż Brytyjczycy byli skłonni zamawiać ubranie i buty u krawca, niż kupować gotowe wyroby w sklepie. A ponieważ krawiectwem przed wojną zajmowali się głównie Żydzi, spośród których niewielu przetrwało Holokaust, zapotrzebowanie na krawców na rynku pracy było bardzo duże ${ }^{101}$.

Griffiths nie dał się jednak przekonać do przyjętej przez polskie władze koncepcji szkolenia niepełnosprawnych w zawodach technicznych. Uważał, że przygotowanie ukierunkowane zbyt wąsko i specjalistycznie nie otwierało takich możliwości zatrudnienia, jak przeszkolenie w różnych dziedzinach, choć mniej gruntowne, jak to robiono w Wielkiej Brytanii. Odradzał też zbytnie koncentrowanie się na amputantach, co, jak zauważył, było cechą charakterystyczną polskiego programu rehabilitacji. Przyznawał, że po każdej wojnie takich osób jest stosunkowo dużo i że człowiek po amputacji jest „w najbardziej oczywisty sposób niepełnosprawny”, przez co całkiem naturalnie budzi uczucia empatii. Griffiths uważał, że odpowiednio zaopatrzony protetycznie i przeszkolony amputant powinien być uważany za osobę pełnosprawną, bo zdolną do „normalnej pracy w normalnym wymiarze czasu”. Zamiast skupiać się na osobach po amputacjach, które stosunkowo najłatwiej rehabilitować zawodowo, postulował podjęcie działań długofalowych uwzględniających niepełnosprawności wynikające nie z działań wojennych, lecz będące skutkiem chorób lub wypadków w przemyśle, bo takie dominują w czasie pokoju ${ }^{102}$.

Tym, co zdziwiło Griffithsa, gdy podczas swojej drugiej podróży po Polsce odwiedzał ośrodki rehabilitacyjne, była niemal całkowita nieobecność kobiet. A przecież, jak argumentował, Polki „walczyły ramię w ramię z mężczyznami” podczas Powstania Warszawskiego oraz na wszystkich frontach II wojny światowej. W swoim raporcie nie podjął próby wyjaśnienia tej sprawy, wyraził jedynie nadzieję, że prawa kobiet do rehabilitacji nie zostaną w polskim programie „przeoczone"103.

Griffiths wrócił do Anglii na początku kwietnia 1948 r. Niedługo po nim przyjechał do Polski Arthur Platt z Narodowego Instytutu dla Ociemniałych (Institute for the Blind), specjalista w zakresie rehabilitacji osób niewidomych. Jego pobyt w charakterze doradcy zorganizowała ONZ104. Gdy wyjeżdżał z powrotem do Anglii, towarzyszył mu prezes Związku

99 Griffiths użył określenia village settlement.

100 TNA, FO 371/71536, nlb. H. Griffiths, Rehabilitation of the Disabled. Poland 1948, s. 37.

101 Ibid., s. 39.

102 lbid., s. 40.

103 lbid., s. 42.

104 UNA, S-1297-0000-0431, nlb., A. Platt, Services for the Blind in Poland, 05.1948 r. 
Pracowników Niewidomych RP, Włodzimierz Dolański, aby na miejscu przekonać się, jak Brytyjczycy radzą sobie z aktywizacją zawodową osób niewidzących ${ }^{105}$.

Do końca 1948 r. kilkoro kolejnych Polaków przyjechało w podobnym celu do Wielkiej Brytanii. Jednym z kursantów był Marian Garlicki z kliniki chirurgicznej Uniwersytetu Warszawskiego. Wraz z innymi lekarzami z 12 krajów uczestniczył w trzytygodniowym szkoleniu zorganizowanym przez British Council wspólnie z tamtejszymi resortem zdrowia oraz ministerstwem rent i emerytur. Podczas pobytu w Anglii Garlicki odwiedził centrum rehabilitacji w Roehampton, a do kraju wrócił jako gorący zwolennik brytyjskiego modelu rehabilitacji. W pełni zgadzał się z jego podstawową przesłanką, to jest przystosowaniem niepełnosprawnych do samodzielnego wykonywania pracy zarobkowej. Tylko takie rozwiązanie gwarantowało korzyść dla nich samych, jak i dla państwa, które zamiast oczekującego na rentę inwalidy zyskiwało kolejnego płatnika podatków ${ }^{106}$.

Brytyjskie służby dyplomatyczne świadome były potencjału politycznego, jaki drzemał w tego rodzaju kontaktach. Zdaniem Richarda Allena z ambasady brytyjskiej w Warszawie stawką było „podtrzymanie, a nawet wzmocnienie” wśród Polaków „wiary w zachodnie idee i instytucje". Dyplomata w pełni doceniał znaczenie dorobku brytyjskiej rehabilitacji i zdawał sobie sprawę, że wiele krajów pozostawało za nią daleko w tyle. Pisał do Hancocka: „Rosja nie ma nic do zaoferowania w tej dziedzinie i Polacy na Zachodzie muszą szukać inspiracji, a także wiedzy technicznej i eksperckiego wsparcia"107.

\section{Spółdzielczość po polsku czy radziecku?}

Richard Allen bardzo się jednak pomylił. O ile w 1946 i 1947 r. przedstawiciele polskich władz, z którym spotykali się brytyjscy eksperci, wyrażali zainteresowanie, a nawet niekiedy entuzjazm wobec zachodniego modelu rehabilitacji, to niedługo później doszło $w$ tej sprawie do radykalnego zwrotu. Latem 1948 r., a więc zaledwie po kilkunastu miesiącach działalności, zlikwidowano Główny Urząd Inwalidzki, przywracając Wydział Spraw Inwalidzkich w randze departamentu MPiOS ${ }^{108}$. Jego dyrektorem został były wiceprezes GUI, Zygmunt Lancmański, zastępując Ćwika, który w tym czasie był niemal całkowicie zajęty działalnością polityczną i związkową ${ }^{109}$.

W połowie 1949 r., oceniając dotychczasową działalność instytucji państwowych w zakresie pomocy osobom z niepełnosprawnościami, Lancmański określił ją mianem "dreptania w miejscu". Tak było, jego zdaniem, do połowy 1947 r. Później natomiast Polacy ulegli „stosukowo dużym wpływom anglosaskich koncepcji «rehabilitacji»” i dopiero

105 „Głos Anglii” t. 3, 1948, nr 34.

106 „Głos Anglii” t. 3, 1948, nr 48.

107 TNA, FO 371/71536, nlb., 12.06.1948 r.

108 Dz.U. 1948 nr 34 poz. 229, Ustawa z dnia 25 czerwca 1948 r. o uchyleniu dekretu z dnia 23 stycznia 1947 r. o organach administracji zaopatrzenia inwalidzkiego.

109 Zostawał kolejno członkiem Centralnego Komitetu Wykonawczego PPS, posłem na Sejm, sekretarzem Komitetu Centralnego Polskiej Zjednoczonej Partii Robotniczej i sekretarzem generalnym Komisji Centralnej Związków Zawodowych. Michał Żółtowski błędnie tłumaczył objęcie stanowiska prezesa GUI przez Lancmańskiego śmiercią Ćwika późnym latem 1948 r. Ćwik zmarł 30.07.1968 r. Zob. M. Żółtowski, Henryk Ruszczyc i jego praca dla Niewidomych. Szkic biograficzny, Laski 1994. 
w 1949 r. wpływy te zostały „przezwyciężone na bazie analizy koncepcji” radzieckiej ${ }^{110}$. Zasadniczym jej elementem była „produktywizacja inwalidów”, którą Lancmański uważał za „wyraz rewolucji na odcinku inwalidzkim”111. Poszczególne etapy produktywizacji, czyli leczenie, protezowanie, szkolenie i zatrudnienie, przynajmniej w teorii nie różniły się od dobrze rozumianej rehabilitacji zawodowej praktykowanej na Zachodzie ${ }^{112}$. Trudno zatem wskazać jakiekolwiek racjonalne przesłanki uzasadniające narrację o „przezwyciężaniu” anglosaskich wzorców i zastępowaniu ich radzieckimi, w którym chodziło przecież o to samo - o „przywracanie zdrowia, zdolności do pracy i niezależności gospodarczej jednostce, która je utraciła", czy też, jak podsumował po rosyjsku Lancmański, o vozvrashcheniye trudovoy zhizni (o powrót do życia zawodowego) ${ }^{113}$.

Dużym uproszczeniem byłoby sądzić, że o porzuceniu brytyjskich wzorców zadecydowały zmiany personalne w ministerstwie. Zarówno Griffiths, jak i Pickersgill postrzegali Ćwika za najgorętszego orędownika anglosaskiej koncepcji rehabilitacji. Ten pierwszy uważał go nawet za „anglofila”114. Gdyby znali jego, „tyleż burzliwe, co zagadkowe curriculum vitae", byliby zapewne w swoich oczekiwaniach wobec Ćwika bardziej powściągli$w^{115}$. Był to przede wszystkim polityczny aktywista, który już w okresie londyńskim pokazał, że interes partyjny jest dla niego najważniejszy. W końcu 1944 r. jego działalność jako referenta do spraw inwalidzkich w MPiOS wywołała falę niezadowolenia wśród członków Związku Inwalidów Wojennych Armii Polskiej w Wielkiej Brytanii. Lekceważąc opinię weteranów, Ćwik doprowadził do obsadzenia stanowisk w Trybunale Odwoławczym przez swoich kolegów partyjnych z PPS. Zdaniem prezesa Związku, Jakuba Sysaka, nie dawało to gwarancji niezależności organu, którego zadaniem było bezstronne rozpatrywanie odwołań niepełnosprawnych weteranów od decyzji organów rentowych. „Wszystko, co p. Ćwik czyni na terenie inwalidzkim wzbudza nieufność, [i] zastrzeżenie co do jego poszanowania przepisów prawnych" - stwierdzał Sysak ${ }^{116}$. Jeszcze dobitniej działalność Ćwika oraz drugiego referenta w ministerstwie, mecenasa Mieczysława Litauera, skomentowali autorzy artykułu, który ukazał się pod koniec 1944 r. w biuletynie „Prawda” wydawanym przez Związek. Narzekając na uznaniowe obniżanie świadczeń i ich przewlekłą realizację, wzywali, aby położyć kres „królikarni doświadczalnej”, jaką w referacie inwalidzkim ministerstwa zaprowadzili Ćwik i Litauer ${ }^{117}$.

110 Z. Lancmański, Produktywizacja inwalidów, „Praca i Opieka Społeczna” 1949, nr 3-4, s. 139.

111 lbid., s. 140.

112 W praktyce dbałość o dobrostan osób z niepełnosprawnościami w Związku Radzieckim pozostawiała wiele do życzenia. Z bogatego dorobku studiów nad niepełnosprawnością w tym kraju wyłania się obraz ciągłej walki osób z niepełnosprawnościami o pracę, renty, a nawet o dostęp do protez. Trudności te w równym stopniu dotyczyły cywilów, jak i inwalidów wojennych, których w oficjalnej narracji prezentowano jako bohaterów, a którzy w codziennym życiu doświadczali dyskryminacji. Zob. m.in. The Disabled in the Soviet Union. Past and Present, Theory and Practice, red. W. McCagg L. Siegelbaum , Pittsburgh 1998; B. Fieseler, The Bitter Legacy of the 'Great Patriotic War'. Red Army Disabled Soldiers under Late Stalinism, [w:] Late Stalinist Russia Society between Reconstruction and Reinvention, red. J. Fürst, Londyn 2006, s. 46-61; Disability in Eastern Europe and the Former Soviet Union History, Policy and Everyday Life, red. M. Rasell, E. larskaia-Smirnova, Londyn 2014; F. Bernstein, Prosthetic Manhood in the Soviet Union at the End of World War II, "Osiris" t. 30, 2015, nr 1, s. 113-133; idem, The History of Disability during Stalinism, [w:] Life in Stalin's Soviet Union, red. K. Boterbloem, Londyn 2019, s. 115-138.

113 Z. Lancmański, op. cit., s. 140.

114 UNA, S-1450-0000-0336, nlb., H. Griffiths, Rehabilitation of the Disabled in Poland, s. 13.

115 T. Marczak, op. cit., s. 244.

116 Archiwum Instytutu Sikorskiego i Muzeum im. Gen. W. Sikorskiego, sygn. PRM 169/2, k. 3.

117 Ibid., k. 1. 
Z politycznej działalności Ćwika w okresie londyńskim zadowolony był natomiast Baranow, kierownik Wydziału Zagranicznego Wszechzwiązkowej Komunistycznej Partii (bolszewików) w Moskwie. To on namawiał Wiesława Gomułkę, żeby Ćwika sprowadzić z emigracji do Polski i wykorzystać do pracy w Centralnym Komitecie Wykonawczym PPS, z którym komuniści z PPR prowadzili rozmowy zjednoczeniowe ${ }^{118}$. Jako neofita, a raczej nawrócony na komunizm „renegat” robił wszystko, aby przypodobać się nowej władzy"19. Wątpliwe, aby zaryzykował swoją karierę polityczną, obstając przy wdrożeniu modelu rehabilitacji inspirowanego wzorcami zachodnimi.

Zasadniczą zmianą, jaką w 1949 r. niepełnosprawnym Polakom przyniosło „przezwyciężenie" anglosaskiej koncepcji rehabilitacji, była rezygnacja z dążenia do zatrudniania osób z niepełnosprawnościami w otwartym przemyśle na rzecz spółdzielni. Ćwik, zanim odszedł z GUI, skłaniał się ku opinii, że w warunkach polskich zatrudnienie niepełnosprawnych w przemyśle byłoby „najbardziej racjonalne” z gospodarczego i społecznego punktu widzenia ${ }^{120}$. Lancmański już po objęciu kierownictwa WSI zachwalał zalety spółdzielczości inwalidów opartej na wzorcu radzieckim jako rozwiązania, które „niewątpliwie odegra doniosłą rolę w racjonalnym rozwiązaniu zatrudnienia inwalidów"121. W jego poglądach na tę sprawę musiała zajść istotna zmiana, bowiem jeszcze rok wcześniej nie wydawał się być wielkim zwolennikiem spółdzielczości. Co więcej, z danych, które przytaczał na początku 1948 r., nie wynikało, by odgrywała ona "doniosłą" rolę za wschodnią granicą: w okresie wojny w spółdzielniach pracowało zaledwie $7 \%$ niepełnosprawnych Rosjan, podczas gdy w przemyśle - aż $44 \%{ }^{122}$. Po wojnie proporcje te zaczęły się odwracać. Aby zrobić miejsce dla powracających z wojny pełnosprawnych weteranów, fabryki masowo zwalniały osoby z niepełnosprawnościami ${ }^{123}$. Część z nich przeszła do pracy w spółdzielniach ${ }^{124}$.

Idea spółdzielczości inwalidów nie była bynajmniej pomysłem radzieckim, zakłady tego typu działały również w międzywojennej Polsce ${ }^{125}$. Nawet Howard Rusk, ame-

118 T. Marczak, op. cit., s. 246.

119 W pierwszym okresie wojny Ćwik, rozczarowany napaścią na Polskę przez Związek Radziecki, zerwał z KPP i przystąpił do PPS, później jednak szukał zbliżenia z Polską Partią Robotniczą (PPR). Osóbka-Morawski uważał, że Ćwik, chcąc „przypodobać się komunistom” i żeby mu przebaczyli, prowadził przeciw niemu „najbardziej brudną robotę". Ostatecznie jednak komuniści nie zapomnieli mu odejścia z KPP i „po zlikwidowaniu wszystkich niezależnych socjalistów” z PPS „wykończyli" i jego pod pretekstem skandalu obyczajowego. W 1953 r. wyrzucono go z PZPR i pozbawiono wszystkich stanowisk. Został rehabilitowany (w sensie politycznym) w $1956 \mathrm{r}$. ale nie powrócił na eksponowane stanowiska, choć zachował wiele znajomości w najwyższych kręgach władzy. Z uwagi na fakt, że na jego powrocie do kraju w 1945 r. bardzo zależało komunistom radzieckim, uważa się, że jego krajowa kariera sterowana była z Moskwy. T. Marczak, op. cit., s. 244-246.

120 T. Ćwik, Powojenny rozwój zagadnień inwalidzkich, „Praca i Opieka Społeczna” 1948, nr 2, s. 85

121 Ibid., s. 142.

122 Dane przytoczone przez Lancmańskiego dotyczyły Rosyjskiej Socjalistycznej Federacyjnej Republice Radzieckiej (RSFRR), Z. Lancmański, Inwalidzi wojenni w Związku Radzieckim, „Praca i Opieka Społeczna” t. 22, 1948, nr 2, s. 109. Podobnie jak w Wielkiej Brytanii najprawdopodobniej byli to pracownicy amunicyjni lub zatrudnien w miejsce sprawnych robotników powołanych do służby wojskowej.

123 B. Fieseler, Soviet-Style Welfare: the Disabled Soldiers of the "Great Patriotic War", [w:] Disability in Eastern Europe, s. 18-41.

124 Spółdzielnie inwalidów działały w Sowieckiej Rosji od 1921 r., gdy powstało Wszechrosyjskie Stowarzyszenie Inwalidów (ros. Vserossiyskoye invalidnoye kooperativnoye obshchestvo - VIKO). W połowie lat pięćdziesiątych w RSFRR było 650 spółdzielni inwalidów, w których pracowało 280 tysięcy niepełnosprawnych. Ponadto działało tam około 2000 innych spółdzielni produkcyjnych, zatrudniających milion osób. Zob. United States Social Security Administration, A Report on Social Security Programs in the Soviet Union. Prepared by the U. S. Team that Visited the U.S.S.R. Under the East-West Exchange, Waszyngton 1960, s. 74.

125 M. Garbat, Geneza i rozwój rehabilitacji zawodowej oraz zatrudniania osób z niepełnosprawnością na ziemiach 
rykański ekspert w dziedzinie rehabilitacji uważał, że niepełnosprawni Polacy mieli niejako naturalną tendencję do zrzeszania się w spółdzielniach. Jako przykład wskazywał grupę inwalidów, którzy zanim jeszcze II wojna światowa dobiegła końca, spontanicznie zrzeszając się podjęli produkcję mydła, proszku do mycia zębów i innych towarów ${ }^{126}$. Najprawdopodobniej chodziło mu o Spółdzielnię Wytwórców "Świt”, założoną 15 października 1944 r. ${ }^{127}$ Początkowo jednak spółdzielczość inwalidzka rozwijała się w Polsce stosunkowo niemrawo. Do końca 1948 r. w kraju działało zaledwie 10 takich zakładów, jednak do 1 lipca następnego roku, gdy powołano Centralę Spółdzielni Inwalidów (CSI), było ich już $164^{128}$. W skład CSI, łamiąc podstawową zasadę spółdzielczości, czyli samorządność, przymusowo włączono wszystkie zakłady usługowe i produkcyjne prowadzone przez Związek Inwalidów Wojennych RP, Związek Pracowników Niewidomych i inne organizacje zrzeszające osoby z niepełnosprawnościami ${ }^{129}$. W ciągu kolejnych pięciu lat liczba spółdzielni inwalidów wzrosła do 340, a zatrudnionych niepełnosprawnych - do 57 tysię$\mathrm{cy}^{130}$. W październiku 1954 r. w ramach unifikacji całego ruchu spółdzielczego do nowo powołanego Centralnego Związku Spółdzielczości Pracy (CZSP) włączono wszystkie cztery działające w Polsce centrale, w tym również CSI. Po dwóch latach okazało się, że moloch nie spełniał pokładanych w nim nadziei. Lista pretensji niepełnosprawnych spółdzielców była długa: w ramach „słusznej w zasadzie” akcji wyodrębniania branż wiele spółdzielni inwalidów zostało włączonych do spółdzielni pracy, z funduszu inwestycyjnego niepełnosprawni otrzymywali mniej środków, niż do niego wpłacali, na szczeblu terenowym lekceważono zalecenia władz CZSP o priorytetowym zaopatrzeniu spółdzielni inwalidów w surowce i maszyny, a nawet niedopuszczanie niepełnosprawnych spółdzielców do dawnych ośrodków wypoczynkowych $\mathrm{CSI}^{131}$. W efekcie zamiast spodziewanego rozwoju bazy dla rehabilitacji członków i poszerzenia możliwości działalności, spółdzielczość inwalidzka zaczęła się kurczyć. Na początku 1957 r., uginając się pod żądaniem niepełnosprawnych spółdzielców, władze zgodziły się wyodrębnić z CZSP Związek Spółdzielni Inwalidów.

W tym samym czasie w Związku Radzieckim w ramach centralizacji gospodarki rozpoczętej w 1956 r. została zlikwidowana cała spółdzielczość produkcyjna. Uznano, że skoro cechuje ją niższa efektywność pracy w przeliczeniu na jednego robotnika niż w zakładach państwowych, to spółdzielnie nie mają racji bytu ${ }^{132}$. Początkowo wydawało się, że wła-

polskich, [w:] Osoby z niepełnosprawnościami w polityce społecznej. Tom 1: praca zawodowa, red. M. Paszkowicz, M. Garbat, Zielona Góra 2013, s. 24-28.

126 H.A. Rusk, D.V. Wilson, New Resources for Rehabilitation and Health, "The Annals of the American Academy of Political and Social Science" t. 329, 1960, s. 101.

127 Rocznik przemysłu odrodzonej Polski. T. 1946-47, red. K. Dąbrowski, Warszawa 1946, s. 106. Co charakterystyczne, odniesienie do kwestii sprawności jej członków pojawiło się w nazwie spółdzielni dopiero w 1949 r., gdy została włączona do Centrali Spółdzielni Inwalidów; od tamtej pory funkcjonowała jako Spółdzielnia Inwalidów „Świt”. Od 2016 r. funkcjonuje jako Spółdzielnia ŚWIT.

128 P. Grata, Przemiany w polskiej polityce zatrudnienia w latach 1944-1949, [w:] Od kwestii robotniczej do nowoczesnej kwestii socjalnej. Studia z polskiej polityki społecznej XX i XXI wieku, t. 5, red. P. Grata, Rzeszów 2017, s. 91.

129 B. Knysz, Integracja osób z dysfunkcją wzroku w opiniach zainteresowanych i w opiniach otoczenia społecznego, rozprawa doktorska, Uniwersytet Śląski, Wydział Nauk Społecznych, Instytut Socjologii, Katowice 2007, s. 55.

130 W. Grochowski, J. Kochanowski, E. Perskiewicz, K. Wlezień, X lat spółdzielczości inwalidzkiej w Polsce, Warszawa 1959 , s. 9.

131 Ibid., s. 10-11.

132 A. White, Democratization in Russia under Gorbachev, 1985-91: The Birth of a Voluntary Sector, Nowy Jork 1998 , s. 45. 
dze radzieckie zachowają chociaż spółdzielczość inwalidzką, ale i ona uległa likwidacji133. Zmiany te nie objęły pozostałych państw komunistycznych i szczególnie w Polsce, Czechosłowacji i Bułgarii sektor spółdzielczy przez kilka kolejnych dekad pozostawał głównym pracodawcą osób z niepełnosprawnościami ${ }^{134}$.

Po likwidacji spółdzielni inwalidów w Związku Radzieckim (przed destalinizacją w samej tylko Rosji było ich 650) Polska pozostała głównym kultywatorem tego modelu aktywizacji zawodowej osób z niepełnosprawnościami. Z czasem zaczęto spółdzielczość inwalidzką wręcz utożsamiać z polską szkołą rehabilitacji jako „pełnoprawny, polski pomysł"135. Wspomniany już Rusk uważał nawet przykład Polski jako interesujące rozwiązanie w sytuacji, gdy przy dużej liczbie niepełnosprawnych członków społeczeństwa występował niedobór miejsc pracy ${ }^{136}$. Zresztą tworzenie spółdzielni było jedną z form organizacji zatrudnienia niepełnosprawnych, które w 1955 r. rekomendowała Międzynarodowa Organizacja Pracy, o ile było to „właściwe w narodowym kontekście i spójne z krajową polityką" ${ }^{137}$. Fakt, że spółdzielczość inwalidzka rozwinęła się najbardziej w krajach bloku wschodniego, wynikał głównie z tego, iż po zawłaszczeniu zasadniczej koncepcji spółdzielczości przez komunistów spółdzielnie produkcyjne stały się jedną z form gospodarki nakazowo-rozdzielczej.

Skupienie całej aktywności produkcyjnej i usługowej osób z niepełnosprawnościami w spółdzielniach miało jednak swoje złe strony. Jak w 1992 r. zauważyła Antonina Ostrowska, masowe stosowanie tej formy zatrudnienia doprowadziło do wypaczenia idei rehabilitacji społecznej. Niepełnosprawni, przebywając w pracy w gronie innych niepełnosprawnych, stawali się dla samych siebie grupą odniesień społecznych i wzorców kontaktów. W efekcie dokonująca się w takich warunkach rehabilitacja społeczna nie polegała na integracji z ogółem społeczeństwa, lecz ze społecznością niepełnosprawnych. Zdaniem Ostrowskiej separacyjny model zatrudnienia osób niepełnosprawnych odzwierciedlał dominujące $w$ Polsce przekonanie, że spółdzielnie inwalidów to najwłaściwsze miejsce ich zatrudnienia. Na domiar złego, praca w spółdzielniach bardzo była często monotonna i źle dobrana do fizycznych i psychicznych predyspozycji robotników ${ }^{138}$. To jednak nie wynikało z żadnych nakazów płynących z Moskwy, lecz z mniej lub bardziej zakamuflowanego paternalizmu polskiego społeczeństwa, które uważało, że osoby z niepełnosprawnościami są w stanie wykonywać proste prace siedzące, na ogół zresztą nisko płatne. Postawę taką od pierwszych dni pobytu w Polsce dostrzegali i piętnowali obaj brytyjscy eksperci, a Griffiths określał ją wręcz mianem „obsesji"139.

Unifikacja spółdzielni inwalidów i zarządzanie nimi centralnie stanowiło zaprzeczenie idei samorządności spółdzielców. Często zarządzane były przez pełnosprawnych preze-

133 F.A. Leedy, Producers' Cooperatives in the Soviet Union, „Monthly Labor Review” t.80, 1957, nr 9, s. 1068.

134 Pod koniec okresu komunistycznego w Polsce było 411 spółdzielni inwalidzkich zatrudniających 180 tysięcy osób. Zob. „Głos Pomorza” t. 36, 1988, nr 169.

135 Opinię taką wygłosił Jerzy Mikulski z Centrum Naukowo-Badawczego Spółdzielczości Inwalidów podczas seminarium w Mławie we wrześniu 1993 r. R. Rzebko, Na rynku pracy jest miejsce dla wszystkich pracodawców zatrudniających osoby niepetnosprawne, „Nasze Sprawy” 1992, nr 10, s. 2.

136 H.A. Rusk, D.V. Wilson, op. cit., s. 101.

137 International Labour Organization, Vocational Rehabilitation (Disabled) Recommendation, 1955, nr 99.

138 Tezy Ostrowskiej pochodzą ze skrótu jej referatu Zatrudnianie osób niepełnosprawnych - dylematy modeli, wygłoszonego podczas seminarium w Mławie we wrześniu 1993 r. R. Rzebko, Co separuje, a co integruje? "Nasze Sprawy" 1992, nr 10, s. 3.

139 UNA, S-1450-0000-0336, nlb., H. Griffiths, Rehabilitation of the Disabled in Poland, s. 22. 
sów, dla których najważniejszym kryterium był zysk. Niejednokrotnie więc interes produkcyjny dominował nad rehabilitacyjnym. O wadach takiego modelu aktywizacji zawodowej niepełnosprawni Polacy, Rosjanie i inni mieszkańcy Europy Środkowo-Wschodniej przekonali się dotkliwie w latach dziewięćdziesiątych XX w., gdy w efekcie transformacji ustrojowej, te dotychczas izolowane od normalnej gry rynkowej przedsiębiorstwa w większości upadły ${ }^{140}$.

\section{Rehabilitacja czy usprawnienie?}

Choć komunistyczne władze odrzuciły brytyjski model przywracania osobom z niepełnosprawnościami pełnej sprawności zawodowej i społecznej, w języku polskim na trwałe zadomowił się spolszczony angielski termin rehabilitation opisujący ten proces, czyli „rehabilitacja”"141. Przed wojną, jako termin prawniczy wywodzący się z nowołacińskiego rehabilitatio, „rehabilitacja” oznaczała przywrócenie do czci i praw osobę niewinnie osądzoną ${ }^{142}$. W kontekście społecznym używano go jedynie w odniesieniu do prostytutek, które przygotowywano do „powrotu do życia” w takich placówkach, jak chociażby Dom Pracy Dobrowolnej, założony w Warszawie przez Związek Pracy Obywatelskiej Kobiet w 1933 r. ${ }^{143}$

W odniesieniu do niepełnosprawności terminu „rehabilitacja” po raz pierwszy użył Ćwik podczas I Ogólnopolskiego Zjazdu kierowników referatów i oddziałów spraw inwalidzkich powiatowych i wojewódzkich jednostek administracji publicznej w końcu maja 1946 r. Z pełną świadomością stwierdził, że termin ten, „nieznany dotychczas” w polskim słownictwie w zakresie spraw inwalidzkich, oznacza „przywrócenie inwalidzie zdolności do pracy i umożliwienie mu powrotu, mimo kalectwa, do szeregów pełnowartościowych członków społeczności"144. W podobnym duchu mówił również Opacki, według którego „inwalidą jest tylko ten, kto załamał się psychicznie”. Ćwik i Opacki odwoływali się do brytyjskiego modelu rehabilitacji, z którym obaj mieli styczność w okresie wojny - pierwszy jako pracownik polskiego Ministerstwa Pracy i Opieki Społecznej rządu emigracyjnego, a drugi jako lekarz chirurg II Korpusu ${ }^{145}$.

140 Na przykładzie Bułgarii proces ten omawia Teodor Mladenov w książce Disability and Postsocialism, Nowy Jork 2018, s. 35.

141 Początki takiego rozumienia tego słowa w języku angielskim Griffiths cofa do pierwszych lat XX w. i działalności firmy Goodwill Industries założonej przez Edgara J. Helmsa w Bostonie. Podstawą jej funkcjonowania była zbiórka starych, uszkodzonych mebli, które po wyremontowaniu przez osoby niepełnosprawne były ponownie sprzedawane. Zob. H. E. Griffiths, Zagadnienie rehabilitacji, „Praca i Opieka Społeczna” 1948, nr 2, s. 86-89.

142 Trzaski, Everta i Michalskiego Encyklopedyczny słownik wyrazów obcych: pochodzenie wyrazów, wymowa, objaśnienia pojęć, skróty, przysłowia, cytaty, red. S. Lam, Warszawa 1939, s. 1792; M. Arcta słownik wyrazów obcych: 33.000 wyrazów, wyrażeń i przysłów cudzoziemskich podług zasad pisowni z r. 1936. Pochodzenie wyrazów (etymologję) i wyjaśnienia wstępne oprac. Henryk Ułaszyn, Warszawa 1937, s. 295.

143 H. Siemieńska, Dom Pracy Dobrowolnej, „Praca i Opieka Społeczna” 1936, nr 4, s. 378-381. Dom Pracy Dobrowolnej, nadzorowany przez Sekcję Opieki Moralnej nad Kobietą, był pierwszą w Polsce świecką placówką tego typu.

144 E. Bednarowicz, Pierwszy Ogólnopolski Zjazd, „Praca i Opieka Społeczna” 1946, nr 2, s. 102.

145 Ibid. Treści wystąpienia Ćwika nie udało się odnaleźć. Z jego streszczenia nie wynika wprawdzie, by wprost odwoływał się do przykładu brytyjskiego, jednak przytoczony zarys funkcjonowania wyraźniej wskazywał, że na nim się opierał. Opacki natomiast odnosił się do przykładu brytyjskiego bezpośrednio, stwierdzając wręcz, że „pojęcie inwalidów jako takich prawie [tam] nie istnieje”. Jego artykuł w jednym z kolejnych numerów „Pracy i Opieki Społecznej", dotyczący właśnie praktyki rehabilitacyjnej w Wielkiej Brytanii jest najprawdopodob- 
Ten zainicjowany przez Ćwika i Opackiego transfer angielskiego rehabilitation na polski grunt doznał potężnego wparcia kilka miesięcy później wraz z przyjazdem najpierw Pickersgilla, a później Griffithsa. Przypominając w połowie 1947 r. działalność tego ostatniego „Gazeta Ludowa” czuła się w obowiązku nadal ujmować to słowo w cudzysłów, by wyjaśnić, że pod hasłem „tak zwanej «rehabilitacji»” należało rozumieć rozpowszechnioną na Zachodzie anglosaskim akcję dążącą nie tylko do przywrócenia rannym i inwalidom wojennym względnego fizycznego zdrowia, ale i do wyleczenia ich z wstrząsów nerwowych i urazów psychicznych, jakie wywołała u nich wojna i choroba, i umożliwienie im stuprocentowej wartości zarobkowania ${ }^{146}$.

Nawet celowe zaniżanie oczekiwań wobec osób z niepełnosprawnościami i zatrudnianie ich jedynie do lekkich, niewymagających dużej aktywności ruchowej prac Pickersgill uważał za nienajlepszy sposób „przywrócenia im utraconych praw i przywilejów, bo w rzeczywistości tym przecież jest rehabilitacja"147. Co znamienne, określając opisywany przez to słowo proces jako symboliczne przywrócenie utraconych praw, w tym przypadku do godnej pracy i płacy, obaj Brytyjczycy w rzeczywistości zbliżali się do pierwotnego znaczenia "rehabilitacji” w języku polskim.

Kluczowym potwierdzeniem okrzepnięcia nowego znaczenia tego słowa, był wniosek o przyznanie Orderu Odrodzenia Polski dla Pickersgilla. Ćwik wnioskował o to do ministra pracy i opieki społecznej w sierpniu 1947 roku. W uzasadnieniu prezes GUI wyjaśniał, że Pickersgill to „specjalista z zakresu przysposobienia do pracy (rehabilitacja) inwalidów”148. Wydaje się, że rozpoczęcie stosowania tego terminu w oficjalnej korespondencji prowadzonej przez kierownictwo GUI miało decydujące znaczenie dla procesu dalszego upowszechniania się nowego znaczenia tego słowa.

Proces ten miał zagorzałego przeciwnika w osobie językoznawcy, Witolda Doroszewskiego. Wyznawał on zasadę unikania konfliktów treści znaczeniowej terminów specjalistycznych z poczuciem językowym ogółu mówiących i zgodnie z nią za niekorzystne uważał stosowanie słowa oznaczającego tradycyjne przywracanie czci w znaczeniu, jak to ujął, „usprawniania”. Na poparcie tezy o konflikcie, i to wykraczającym poza sferę znaczeniową, przywoływał list, jaki pensjonariusze sanatorium dla gruźlików w Szklarskiej Porębie skierowali swego czasu do Polskiego Radia. Protestowali w nim przeciwko nazywaniu procesu przywracania im zdrowia i zdolności do pracy „akcją rehabilitacyjną”149. Jak pisali, „chory na gruźlicę nie jest splamiony na honorze, nie trzeba go rehabilitować"150. Doroszewski słusznie zauważał, że wyraz używany w nowym kontekście trafił do polszczyzny z języka angielskiego, jednak wywodził go od czasownika rehabilitare oznaczającego „odbudowywanie", na przykład miast ${ }^{151}$. Językoznawca zaznaczał, że przeciwko używaniu

niej rozwinięciem tez wygłoszonych podczas zjazdu. Zob. K. Opacki, Rehabilitacja szpitalna inwalidów, „Praca i Opieka Społeczna" 1946, nr 4, s. 243-245.

146 „Gazeta Ludowa” t. 3, 1947, nr 169.

147 Their Mission to Poland's Disabled, s. 12-13.

148 AAN, MPiOS, sygn. 405, k. 99.

149 Przypadek ten Doroszewski opisał obszernie w t. 1 książki O kulturę słowa. Poradnik językowy, Warszawa 1970.

150 W. Doroszewski, Rehabilitacja, rewalidacja oraz parę określeń z zakresu pedagogiki specjalnej, „Poradnik Językowy" 1970, nr 1, s. 56.

151 W miejsce „rehabilitacji” Doroszewski podsuwał „rewalidację" - wyraz, którego budowę słowotwórczą opierał na łacińskim validus i jego antonimie - invalidus. Uważał, że wywodząc się z łacińskiego validus, czyli „zdrowy, zdolny, sprawny” wyraz „rewalidacja” trafniej oddaje treść znaczeniową czynności polegającej na uczynieniu 
słowa „rehabilitacja” w znaczeniu medycznym przemawiała nie jego obcość w języku polskim, lecz to, że miało w nim inne znacznie, nie wiedząc zapewne, że Pickersgill i Griffiths tak go właśnie używali, i to z pełną tego świadomością, nadając $w$ ten sposób procesowi rehabilitacji daleko bardziej emancypujący i głęboko humanitarny charakter.

\section{Zakończenie}

Rezygnując w 1949 r. z wdrażania rekomendowanego przez specjalistów brytyjskich integracyjnego modelu rehabilitacji osób z niepełnosprawnościami, polskie władze kierowały się względami politycznymi. W rezultacie krajowy system rehabilitacji rozwijał się dwoma nurtami, medycznym i zawodowym, które dopiero po latach zaczęły ewoluować w stronę rozwiązań kompleksowych, jakie Brytyjczycy starali się zaszczepić w Polsce tuż po wojnie. Krytyczne spojrzenie na ten okres w dziejach polskiej rehabilitacji wskazuje, że oprócz względów politycznych poważną przeszkodą na drodze do adaptacji modelu integracyjnego był krytykowany przez brytyjskich ekspertów, głęboko zakorzeniony paternalizm polskiego społeczeństwa. Zignorowanie ich ostrzeżeń i sugestii zaowocowało utrwaleniem się na dekady modelu separacyjnego, w którym osoby z niepełnosprawnościami postrzegano raczej jako obciążenie dla społeczeństwa niż jako kapitał.

\section{Bibliografia}

\section{Źródła archiwalne}

Archiwum Akt Nowych, Warszawa [AAN], Zespół Ministerstwa Pracy i Opieki Społecznej (MPiOS).

Archiwum Instytutu Sikorskiego i Muzeum im. Gen. W. Sikorskiego w Londynie, Zespół Prezydium Rady Ministrów (PRM).

The National Archives, Londyn, Wielka Brytania [TNA], Zespół Foreign Office (FO).

United Nations Archives, Nowy Jork, Stany Zjednoczone [UNA], Zespół United Nations Relief and Rehabilitation Administration.

\section{Źródła drukowane}

Dekret z dnia 23 stycznia 1947 r. o organach administracji zaopatrzenia inwalidzkiego, Dz.U. 1947 nr 21 poz. 83.

International Labour Organization, Vocational Rehabilitation (Disabled) Recommendation, 1955, nr 99.

sprawnym, zdrowym tego, komu tych cech brakowało, kto był invalidus, czyli „niesprawny, niedołężny”. Tłumacząc budowę słowotwórczą tego wyrazu, inspirował się twórczością Horacego, który w jednym z poematów scharakteryzował jednego z bohaterów: mente minus validus quam corpore toto - „umysłowo mniej sprawny, mniej wart niż fizycznie". Wyraz ten znalazł się, co nie bez dumy zaznaczał Doroszewski, w redagowanym przezeń słowniku języka polskiego (zob. W. Doroszewski, op. cit., s. 57). Nie do obrony natomiast wydaje się uporczywie powtarzany w polskim piśmiennictwie pogląd wywodzący wyraz rehabilitacja od nowołacińskiego habilis, znaczącego tyle, co "łatwy do ujęcia, zdatny, wygodny, giętki”, choć oba słowa, zarówno angielskie rehabilitation w sensie odbudowy, jak i polski termin oznaczający przywracanie praw honorowych, są wobec niego wtórne. Pisał o tym m.in. Andrzej Sieczkowski w „Poradniku Językowym” (1975, nr 2, s. 106). 
Rocznik przemysłu odrodzonej Polski. T. 1946-47, red. K. Dąbrowski, Warszawa 1946. United States Social Security Administration, A Report on Social Security Programs in the Soviet Union. Prepared by the U. S. Team that Visited the U.S.S.R. Under the East-West Exchange, Waszyngton 1960.

Ustawa z dnia 25 czerwca 1948 r. o uchyleniu dekretu z dnia 23 stycznia 1947 r. o organach administracji zaopatrzenia inwalidzkiego, Dz.U. 1948 nr 34 poz. 229.

\section{Źródła prasowe}

„Dziennik Polski i Dziennik Żołnierza”.

"Gazeta Ludowa".

"Głos Anglii".

"Głos Narodu".

"Głos Pomorza".

"Nasze Sprawy".

"New Poland".

"The Observer".

"Robotnik".

"Życie Warszawy".

\section{Literatura przedmiotu}

X lat spółdzielczości inwalidzkiej w Polsce, red. W. Grochowski, Warszawa 1959.

Bednarowicz E., Pierwszy Ogólnopolski Zjazd, „Praca i Opieka Społeczna” 1946, nr 2, s. 101-102.

Bernstein F., Prosthetic Manhood in the Soviet Union at the End of World War II, "Osiris" t. 30, 2015, nr 1, s. 113-133, DOI 10.1086/682969.

Bernstein F., The History of Disability during Stalinism, [w:] Life in Stalin's Soviet Union, red. K. Boterbloem, Londyn 2019, s. 115-138.

Brenk M., Aktywizacja osób niepełnosprawnych w propagandzie Polski Ludowej lat 1946-1956, [w:] Reintegracja - Edukacja - Adaptacja. Aktywizacja zawodowa i społeczna osób zagrożonych wykluczeniem, red. M. Kowalski, A. Knocińska, P. Frąckowiak, Gniezno 2015, s. 312-323.

British Council for Rehabilitation, „British Medical Journal”, 21.04.1945 r., s. 564.

Ćwik T., Powojenny rozwój zagadnień inwalidzkich, „Praca i Opieka Społeczna” 1948, nr 2, s. 83-85.

Disability in Eastern Europe and the Former Soviet Union History, Policy and Everyday Life, red. M. Rasell M, E. larskaia-Smirnova, Londyn 2014, DOI 10.4324/9781315866932.

Doroszewski W., Rehabilitacja, rewalidacja oraz parę określeń z zakresu pedagogiki specjalnej, „Poradnik Językowy” 1970, nr 1, s. 56-59.

Fieseler F., The Bitter Legacy of the 'Great Patriotic War'. Red Army Disabled Soldiers under late Stalinism, [w:] Late Stalinist Russia Society between Reconstruction and Reinvention, red. J. Fürst, Londyn 2006, s. 46-61.

Garbat M., Geneza i rozwój rehabilitacji zawodowej oraz zatrudniania osób z niepełnosprawnością na ziemiach polskich, [w:] Osoby z niepełnosprawnościami w polityce społecznej. Tom 1: praca zawodowa, red. M. Paszkowicz, M. Garbat, Zielona Góra 2013, s. 19-35. 
Gilbreth F., Gilbreth L., Motion Study for the Handicapped, Londyn 1920.

Grata P., Czas przełomu. Polska polityka społeczna w latach 1944-1950, Rzeszów 2018.

Grata P., Przemiany w polskiej polityce zatrudnienia w latach 1944-1949, [w:] Od kwestii robotniczej do nowoczesnej kwestii socjalnej. Studia z polskiej polityki społecznej XX i XXI wieku, t. 5, red. P. Grata, Rzeszów 2017, s. 75-96.

Griffiths H.E., Zagadnienie rehabilitacji, „Praca i Opieka Społeczna” 1948, nr 2, s. 86-89.

Hulek A., Analiza pracy - metoda i technika, „Praca i Opieka Społeczna” 1948, nr 4, s. 257-262.

Hulek A., Czynnościowa analiza pracy (na marginesie zatrudnienia ciężko poszkodowanych inwalidów w przemyśle), „Praca i Opieka Społeczna” 1948, nr 2, s.101-104.

Hulek A., Rehabilitacja inwalidów w Polsce, Warszawa 1957.

Hulek A., Teoria i praktyka rehabilitacji inwalidów: analiza w aspekcie fizycznym, psychologicznym, społecznym i zawodowym, Warszawa 1969.

Hulek A., Z dziejów polskiej rehabilitacji inwalidów i innych osób niepełnosprawnych jako służby społecznej, Warszawa 1998.

Illingworth F., Limbless Ex-servicemen Now Walk and Work, „The War Illustrated” 1946, nr 229, s. 747-749.

Jandziś S., Rehabilitacja lecznicza w okresie Polskiej Rzeczypospolitej Ludowej, „Przegląd Medyczny Uniwersytetu Rzeszowskiego i Narodowego Instytutu Leków w Warszawie” t. 8, 2010, nr 4, s. 505-511.

Knysz B., Integracja osób z dysfunkcją wzroku w opiniach zainteresowanych i w opiniach otoczenia społecznego, rozprawa doktorska, Uniwersytet Śląski, Wydział Nauk Społecznych, Instytut Socjologii, Katowice 2007.

Lancmański Z., Inwalidzi wojenni w Związku Radzieckim, „Praca i Opieka Społeczna” t. 22, 1948, nr 2, s. 104-111.

Lancmański Z., Produktywizacja inwalidów, „Praca i Opieka Społeczna” 1949, nr 3-4, s. 138-143.

Leedy F.A., Producers' Cooperatives in the Soviet Union, "Monthly Labor Review" t. 80, 1957, nr 9, s. 1064-1068.

Lubecki M., Rola ośrodków rehabilitacyjno-ortopedycznych w polskim modelu rehabilitacji medycznej w drugiej połowie XX wieku, rozprawa doktorska, Uniwersytet Medyczny im. Karola Marcinkowskiego w Poznaniu, Poznań 2010.

Łaptoś J., Humanitaryzm i polityka. Pomoc UNRRA dla Polski i polskich uchodźców w latach 1944-1947, Kraków 2018.

Łotysz S., Penicylina i protezy. Pomoc UNRRA w odbudowie polskiego przemysłu medycznego po Il wojnie światowej, „Kultura Współczesna: teoria, interpretacje, krytyka” 2018, nr 3, s. 118-130, DOI 10.26112/kw.2018.102.10.

Michała Arcta słownik wyrazów obcych: 33.000 wyrazów, wyrażeń i przysłów cudzoziemskich podług zasad pisowni z r. 1936. Pochodzenie wyrazów (etymologję) i wyjaśnienia wstępne oprac. Henryk Ułaszyn, Warszawa 1937.

Marek-Ruka M., Rehabilitacja społeczna osób niepełnosprawnych, Warszawa 1999.

Mladenov T., Disability and Postsocialism, Nowy Jork 2018, DOI 10.4324/9781315306834.

Opacki K., Rehabilitacja szpitalna inwalidów, „Praca i Opieka Społeczna” 1946, nr 4, s. 243-245.

Rehabilitacja polska 1945-2009, red. J. Kiwerski, Wrocław 2009. 
Rusk H.A., Wilson D.V., New Resources for Rehabilitation and Health, „The Annals of the American Academy of Political and Social Science" t. 329, 1960, s. 97-106.

Rutkiewicz A., Służba zdrowia 1. Samodzielnej Brygady Spadochronowej-organizacja, wyszkolenie, działania 1941-1947, rozprawa doktorska, Instytut Historii Nauki im. L.

i A. Birkenmajerów PAN, Warszawa 2019.

Rzebko R., Co separuje, a co integruje?, „Nasze Sprawy” 1992, nr 10, s. 3.

Rzebko R., Na rynku pracy jest miejsce dla wszystkich pracodawców zatrudniających osoby niepełnosprawne, „Nasze Sprawy” 1992, nr 10, s. 2.

Sawicki J., Misja UNRRA w Polsce: raport zamknięcia (1945-1949), Lublin 2017.

The Disabled in the Soviet Union. Past and Present, Theory and Practice, red. W. McCagg,

L. Siegelbaum, Pittsburgh 1998.

Trzaski, Everta i Michalskiego Encyklopedyczny słownik wyrazów obcych: pochodzenie wyrazów, wymowa, objaśnienia pojęć, skróty, przysłowia, cytaty, red. S. Lam, Warszawa 1939.

Sieczkowski, A., Co piszą o języku?, „Poradnik Językowy” 1975, nr 2, s. 104-106.

Siemieńska H., Dom Pracy Dobrowolnej, „Praca i Opieka Społeczna” 1936, nr 4, s. 378-381.

Waszkowski H., Ruch spółdzielczości inwalidów i jego znaczenie dla rozwoju rehabilitacji osób niepełnosprawnych w Polsce, „Niepełnosprawność” 2016, nr 4, s. 97-122.

White A., Democratization in Russia under Gorbachev, 1985-91: The Birth of a Voluntary Sector, Nowy Jork 1998, DOI 10.1007/978-1-349-27372-0.

Żółtowski M., Henryk Ruszczyc i jego praca dla Niewidomych. Szkic biograficzny, Laski 1994.

\section{Strony internetowe}

World Health Organization and World Bank, World report on disability 2011, Genewa 2011, s. 308, apps.who.int/iris/handle/10665/44575 [dostęp 20.04.2020].

Hanger, Inc. www.hanger.com/ [dostęp 20.04.2020].

Finansowanie

Projekt badawczy został sfinansowany przez Państwowy Fundusz Rehabilitacji Osób Niepełnosprawnych w ramach grantu nr BEA/000046/BF/D.

\section{Podziękowania}

Autor pragnie podziękować dwóm anonimowym recenzentom, których uwagi przyczyniły się do nadania tej pracy ostatecznego kształtu. Wielką pomoc w dotarciu do źródeł okazali pracownicy archiwów i bibliotek w Warszawie, Londynie i Nowym Jorku. Wielkie podziękowania płyną również do Marzeny Lizurej i Magdaleny Zdrodowskiej. 
dr hab. Sławomir Łotysz jest historykiem techniki zatrudnionym w Instytucie Historii Nauki im. L. i A. Birkenmajerów PAN na stanowisku profesora. Zajmuje się dziejami wynalazczości, a także zagadnieniami transferu i recepcji idei technicznych w powojennej Europie oraz historią środowiskową Polski. W kadencji 2017-2021 pełni funkcję przewodniczącego Międzynarodowego Komitetu Historii Techniki (ICOHTEC).

e-mail: s.lotysz@gmail.com

Data zgłoszenia artykułu: 15 maja 2020

Data przyjęcia do druku: 26 października 2020 